

\section{Acknowledgments and Disclaimer}

This report is authored by Irem Guceri (Tax Policy Expert, Oxford University Centre for Business Taxation Research Fellow) with contributions from Andrey Zolotarev (Innovation Policy Specialist). The team was led by Anwar Aridi (Innovation Specialist - Task Team Leader), the editor of the report.

The report gratefully benefited from comments provided by Robert Hodgson and David Cheney (Senior Consultants) and feedback provided by several World Bank Group staff.

\section{Disclaimer and Copyright}

(C)2017 The World Bank Group

1818 H Street NW

Washington, DC 20433

Telephone: 202-473-1000

Internet: www.worldbank.org

All rights reserved.

This volume is a product of the staff of the World Bank Group. The World Bank Group refers to the member institutions of the World Bank Group: The World Bank (International Bank for Reconstruction and Development); International Finance Corporation (IFC); and Multilateral Investment Guarantee Agency (MIGA), which are separate and distinct legal entities each organized under its respective Articles of Agreement. We encourage use for educational and non-commercial purposes.

The findings, interpretations, and conclusions expressed in this volume do not necessarily reflect the views of the Directors or Executive Directors of the respective institutions of the World Bank Group or the governments they represent. The World Bank Group does not guarantee the accuracy of the data included in this work.

\section{Rights and Permissions}

The material in this publication is copyrighted. Copying and/or transmitting portions or all of this work without permission may be a violation of applicable law. The World Bank encourages dissemination of its work and will normally grant permission to reproduce portions of the work promptly.

For permission to photocopy or reprint any part of this work, please send a request with complete information to the Copyright Clearance Center Inc., 222 Rosewood Drive, Danvers, MA 01923, USA; telephone: 978-750-8400; fax: 978-750-4470; Internet: www.copyright.com.

All other queries on rights and licenses, including subsidiary rights, should be addressed to the Office of the Publisher, The World Bank Group, 1818 H Street NW, Washington, DC 20433, USA; fax: 202-522-2422; e-mail: pubrights@worldbank.org. 


\section{Table of Contents}

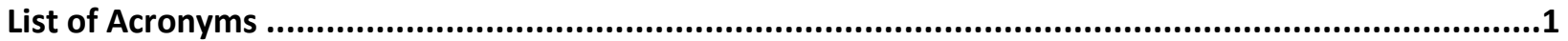

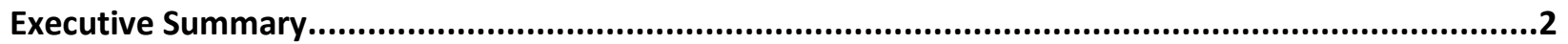

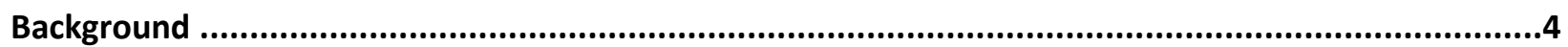

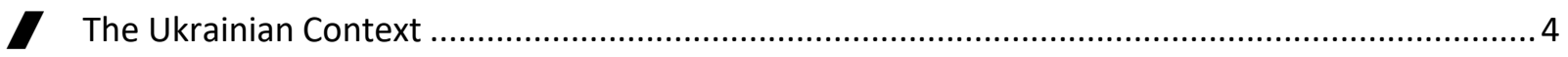

Ukraine's Current Institutional Setting Related to Fiscal Incentives ............................................ 5

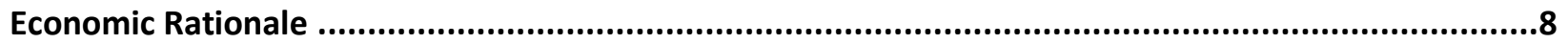

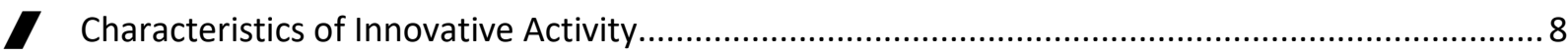

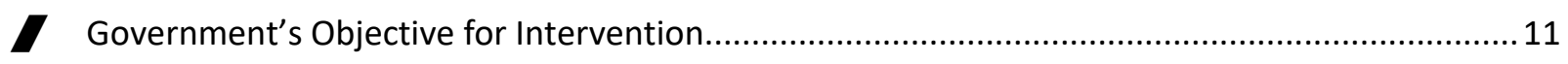

Fiscal Incentive Schemes for Science, Technology, and Innovation................................................12

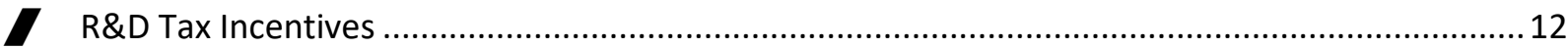

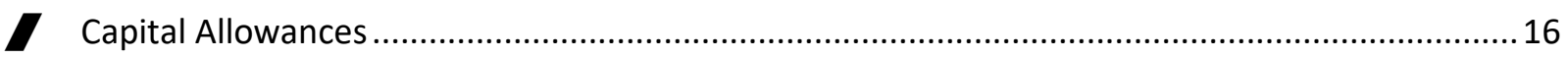

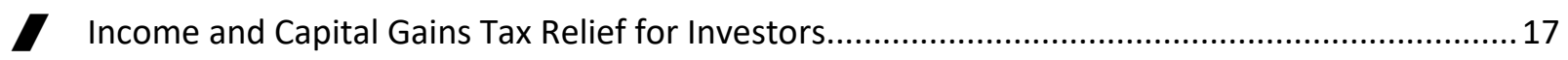

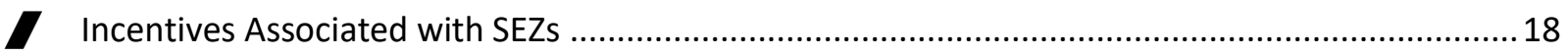

$\boldsymbol{Z}$ VAT or Customs Duty Exemptions for Imported Inputs................................................................20

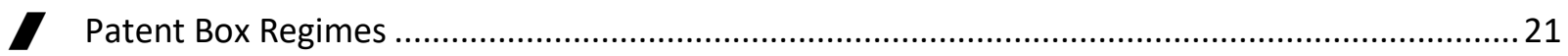

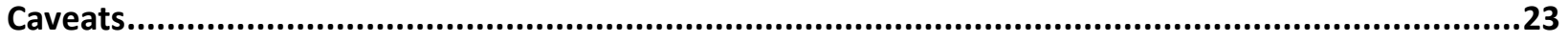

Concluding Remarks and Policy Recommendations ..................................................................25

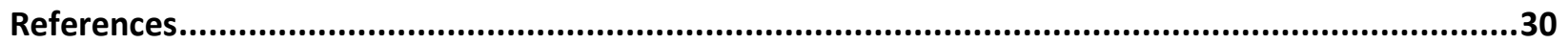

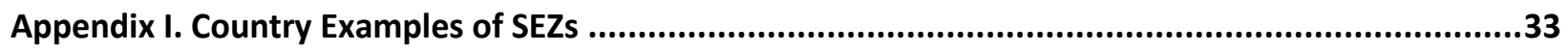




\section{List of Figures}

Figure 1. Number of Patent Applications per Million Population, by Residence of the Applicant ............................. 5

Figure 2. Demonstration of Liquidity Constraints through the Hierarchy of Finance Models.....................................9

Figure 3. The Cycle of Insufficient Equity Financing in Developing Countries .......................................................10

Figure 4. Ranking of R\&D Tax Incentives by Level of Generosity around the World .............................................14

Figure 5. Time Line of Significant Events in France's R\&D Tax Incentive System .................................................15

Figure 6. Investment Responses by the Recipients of Bonus Depreciation.........................................................17

\section{List of Tables}

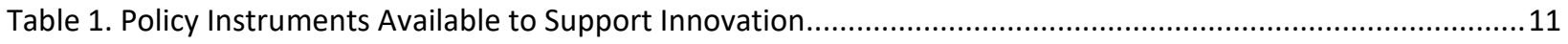

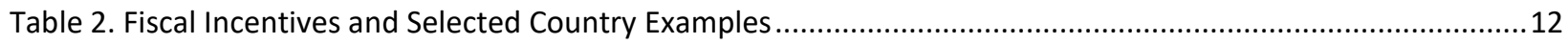

Table 3. Results of a Few Academic Studies on the Effectiveness of Tax Incentives............................................14

Table 4. Deductions and Tax Gain on an Investment of US\$1 Million in Computers ..............................................16

Table 5. Evaluation of Fiscal Incentives to the Government's Intermediate Objectives - by Effectiveness in

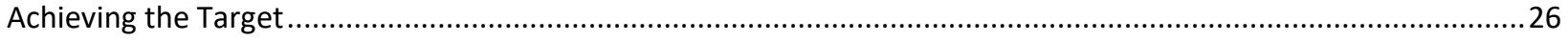

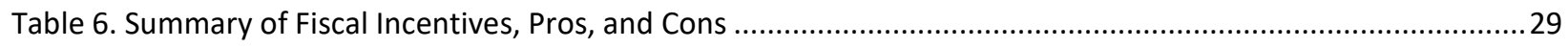

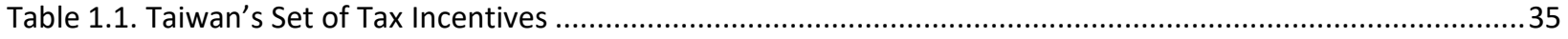

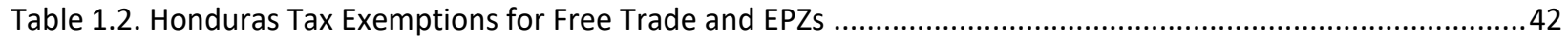




\begin{tabular}{ll} 
CBA & Cost-Benefit Analysis \\
\hline ASAN & Association of Southeast Asian Nations \\
\hline BEPS & Base Erosion and Profit Shifting \\
\hline EIS & Enterprise Investment Scheme \\
\hline EPZ & Export Processing Zone \\
\hline FDI & Foreign Direct Investment \\
\hline GDP & Gross Domestic Product \\
\hline IP & Intellectual Property \\
\hline IPA & Investment Promotion Authority \\
\hline ITA & Income Tax Allowance \\
\hline ITH & Income Tax Holiday \\
\hline MIDA & Malaysian Investment Development Authority \\
\hline NCER & Northern Corridor Economic Region \\
\hline NPV & Net Present Value \\
\hline OECD & Organisation for Economic Co-operation and Development \\
\hline PFR & Public Finance Review \\
\hline PSA & Production Sharing Agreement \\
\hline R\&D & Research and Development \\
\hline SCORE & Sarawak Corridor of Renewable Energy \\
\hline SEIS & Seed Enterprise Investment Scheme \\
\hline SEZ & Special Economic Zone \\
\hline SME & Small and Medium Enterprise \\
\hline STI & Science, Technology, and Innovation \\
\hline STS & Simplified Tax System \\
\hline VAT & Value Added Tax \\
\hline VC & Venture Capital \\
\hline VCT & Venture Capital Trust \\
\hline ZSP & Zhongguancun Science Park \\
\hline
\end{tabular}


This report is one of several analytical pieces developed by the World Bank's Ukraine Technical Assistance on Innovation Support project, supported by the Swedish Ukraine Financial and Enterprise Sector Recovery and Growth Trust Fund. This report reviews different international good practices in introducing fiscal incentives for supporting science, technology, and innovation (STI) and provides policy recommendations relevant to the implementation of such incentives in Ukraine. The three supporting analytical pieces performed by the Ukraine Innovation Support project team are as follows:

- Ukraine Innovation and Entrepreneurship Ecosystem Diagnostic, which attempts to identify the gaps that impede enterprise innovation in Ukraine and develop recommendations for policy reforms and support instruments.

- Ukraine Science, Technology, and Innovation Public Expenditure Analysis, which attempts to evaluate the quality mix of public support programs for STI and provide recommendations for the improvement of the support programs' effectiveness

- Ukraine Intellectual Property and Technology Transfer Regulatory Review, which attempts to identify regulatory and framework impediments for the commercialization of publicly funded research and recommends reforms and policies that could improve the framework conditions for intellectual property (IP) and technology transfer

The present report focuses on tax incentives as an indirect financial support mechanism for the private sector's research and development (R\&D) and innovation activity. The report identifies the costs and benefits of a variety of fiscal incentives to support STI that have been widely used worldwide. In the field of STI, each country's objectives, interests, and infrastructure is unique, and therefore the design of an efficient national innovation system requires a policy mix that is tailored to each country's needs and objectives. On that basis, this report begins by describing the Ukrainian context, focusing on the strengths and weaknesses of Ukraine's science and technology base, followed by a discussion of the recent developments in its corporate tax system as they relate to the private sector's R\&D and innovation efforts.

The private sector underinvests in socially beneficial innovation activities. Governments can improve upon the market outcome, through policy interventions, and increase such private activities. However, just as carefully devised policy instruments may improve upon the free market equilibrium level of investment in innovation activities, adopting a generic set of innovation policies may result in a waste of scarce government resources that could otherwise be used in more productive areas.

A careful consideration of the economic rationale of providing fiscal incentives for innovation activities is therefore crucial in identifying the most effective instruments available for achieving the government's objectives for providing such support. This report lays out a framework that maps government objectives to the economic justification for intervention in areas related to STI. The report suggests suitable fiscal incentives that may address some of the market failures discussed in it. In the absence of any intervention, these market failures result in a suboptimal level of innovation activities in the private sector.

Recently, there has been a surge in the use of fiscal incentives to support private investment in STI. The rise in popularity of such schemes has enabled us to better understand the set of policies that work and those that do not. Impact analyses, based on a wide variety of examples, have helped in identifying 'good practices'. However, these come with caveats; differences among countries mean that a single policy tool will not offer the 'ultimate panacea' for increasing investment in STI. This report notes the importance of 
a country's national innovation system in determining the effectiveness of the available fiscal incentives.

The good practice examples outlined in this report have all been implemented as part of a broader agenda for strengthening the science and technology base of the countries in which they were put in place. Each of the policies, in isolation, would not have been sufficient to achieve the objectives of the government.

Administrative inefficiencies may render any policy initiative ineffective. These may arise from low state capacity, corruption, or, simply, the lack of resources to implement rather complex policies. In addition, political economy aspects may mean that lobby groups and certain large companies make private gains without the policy generating an overall benefit for the society. Ensuring macroeconomic stability and improvements in the business climate should therefore precede tax incentives to support R\&D in Ukraine.

We recommend that Ukraine invests in capacity building to implement fiscal incentives in the future, which involves developing a suitable skill set within the Ministry of Finance to work on (a) cost-benefit analysis of possible future implementation, (b) reliable data collection in private R\&D and innovation efforts, and (c) specialization on evaluating projects related to science and technology. 


\section{The Ukrainian Context}

Ukraine has a long-standing legacy of high-skilled scientists and engineers. In the recent decades, the country's science and technology base, however, has been on the decline. Domestically, poor governance, weak institutions, and inefficiencies in the allocation of public funds for innovation and research and development (R\&D) are among the main contributors to the decline of Ukraine's science, technology, and innovation (STI) base. The lack of private and public funds for R\&D has rendered the physical infrastructure outdated and unable to support the development of cutting-edge technology.

There are external destabilizing factors that have led to a reduction in Ukraine's flow of public funds to the private sector through STI policies. The country has been severely hit by its ongoing crisis with the Russian Federation and the conflict in its eastern region. In 2015, Ukraine's real gross domestic product (GDP) dropped about 10 percent, exports were down by 17 percent, and unemployment hit its highest levels in a decade.

Partly because of the turbulent economic conditions and institutional failures, Ukrainian private efforts in the areas related to STI have been lagging well behind comparators. Figure 1 shows the number of patent applications scaled by population size as an indicator of innovation activities and outputs in Ukraine. The left panel demonstrates the performance of a group of higher GDP per capita countries, namely, the United States, France, the United Kingdom, and Russia, compared with Ukraine. In the early years of its independence, Ukraine's performance matches the performance of Russia, until the 2000s. The gap between Ukraine and advanced economies widens in the subsequent years.

The right panel of Figure 1 presents the evolution of the same metric against other middle-income countries and comparators in the Black Sea Region. Given the narrower scale of the graph, Ukraine's performance over these comparators (Romania, Bulgaria, Turkey, and Brazil) in the 1990s is evident, until the large drop in the early 2000s. In later years, Ukraine experiences further declines in its innovation performance as measured by this metric, and countries such as Bulgaria and Romania appear to catch up, while Turkey's performance exceeds that of Ukraine. 

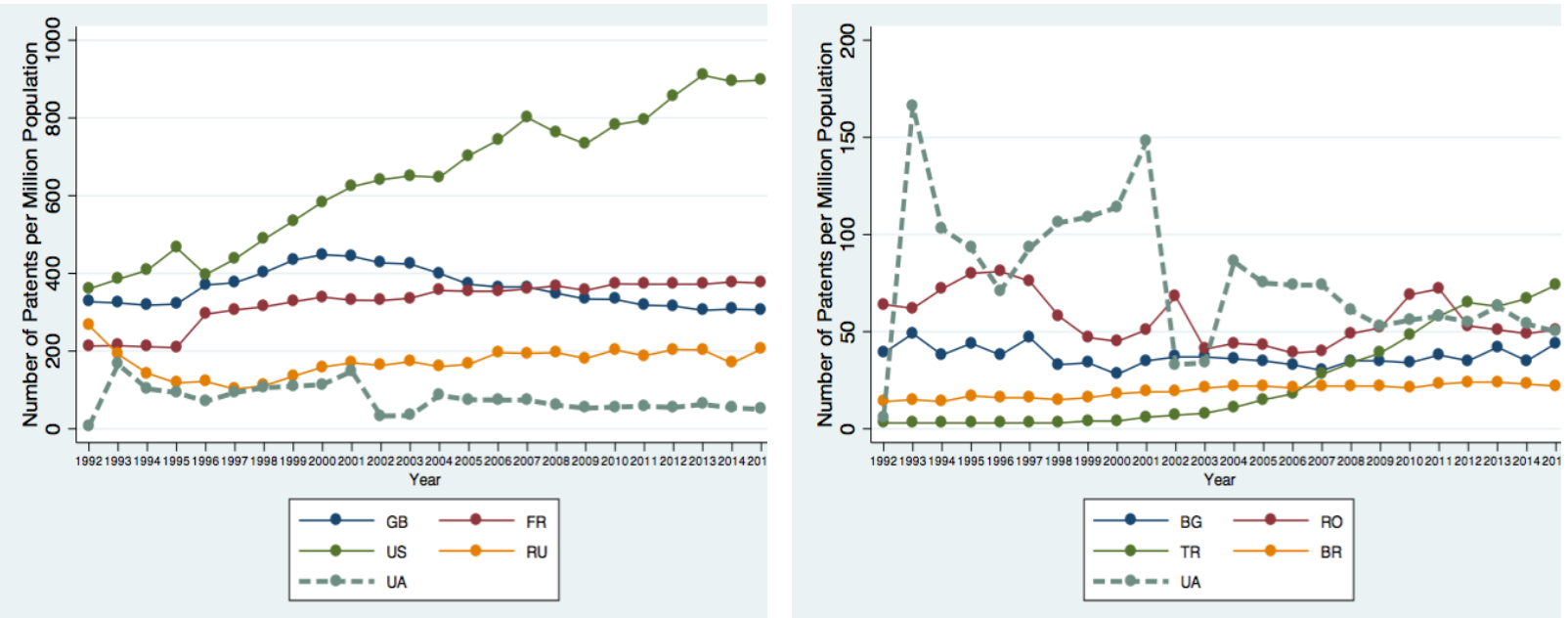

Source: World Intellectual Property Organization IP Statistics Data Centre, November 2016 update for the series (10) resident application per million population (by origin), total count by applicant's origin (equivalent count).

$R \& D$ inputs provide an indicator of the country's potential in generating future innovations, even if the innovation output is not high. The R\&D workforce of Ukraine has been shrinking in the past decade. The number of R\&D personnel (per million population) dropped by more than 30 percent over $2006-2014 .^{1}$ Even before the start of the regional political turmoil, R\&D spending as a share of Ukraine's total output was not high and experienced a declining trend. In 2012 and 2013, the share of R\&D spending in Ukraine's GDP was around 0.76 percent. In 2013, a strong innovator country such as the United States had this ratio at more than 2.7 percent, and middle-income countries such as Turkey and Brazil had ratios of 0.94 percent and 1.24 percent, respectively. On the other hand, Romania had an extremely low R\&D/GDP ratio of around 0.39 percent, and Bulgaria had around 0.64 percent.

\section{Ukraine's Current Institutional Setting Related to Fiscal Incentives}

The science and technology infrastructure in Ukraine is supported by a set of policy measures adopted by the government. This section focuses on the current corporate tax system and fiscal incentives relevant to the STI ecosystem.

The statutory rate of corporate income tax at 18 percent in Ukraine is rather low, compared with 20 percent in the United Kingdom and Russia, 35 percent in the United States and 33.33 percent in France. However, Ukraine taxes corporations on their worldwide income. Ukraine has an open and transparent legal regime for foreign investment that is broadly consistent with international norms. It has a simplified tax system (STS) for small and medium enterprises (SMEs) (which include legal entities with annual revenue of up to UAH 20 million [about US\$809,000]). SMEs pay a single tax, not including others, such as corporate income tax, land tax, duty for special use of natural resources, communal taxes, and duty for obligatory state pension insurance.

The complexity of the tax system in Ukraine contributes to maintaining a large shadow economy, enables tax base erosion, and reaffirms the public's beliefs about corruption. The World Bank's forthcoming Public

\footnotetext{
${ }^{1}$ Source: World Development Indicators.
} 
Finance Review (PFR) (2017) finds that there are significant inefficiencies in Ukraine's tax administration. First, the cost of collecting taxes is high-there are a larger number of revenue officials per taxpayer in Ukraine than in countries similar in size to Ukraine. Second, there are large compliance costs: for a firm, filing taxes takes about 355 hours per year in Ukraine, compared with the Organisation for Economic Cooperation and Development (OECD) average for high-income countries of 163 hours (Doing Business 2017). Third, more than half of businesses believe that they should make informal payments in their dealings related to tax (BEEPS 2013 and PFR 2017).

A highly contested issue in Ukraine is the STS for SMEs. On the one hand, small businesses constitute around 20 percent of gross value added in Ukraine, while this share is around 39 percent for the European Union (EU) (Kravchuk 2015). This indicates that the current system is not successful in promoting small businesses' contribution to the overall economy. The reduction of administrative costs to small businesses brought about by the STS is useful to reduce their cost of doing business. Tax savings are another advantage of the policy. However, the size thresholds distort firm sizes and operations substantially in Ukraine. Entities form multiple sub-firms to keep benefiting from the system. This generates a burden on (a) the tax administration as it loses tax revenue and (b) the firms as they spend valuable time and resources on strategizing around best tax avoidance and evasion tactics. The firms that comply with the rules lose out as well, since companies that manage to remain below thresholds drive the costs down and harm competition.

In 2014, Ukraine undertook significant tax reforms intended to improve the investment climate, stabilize the country's public sector debt, and simplify the tax system. Many reforms were initiated but were later only partially implemented. In the past, the government relied on generous tax incentives to stimulate private investment, but these led to revenue losses without a clear positive impact on the real economy. Public policy for investment promotion was fragmented, with a complex system of tax benefits that were difficult to administer and monitor. The ineffectiveness was due to administrative obstacles and political and macroeconomic instability.

R\&D tax incentives or patent box ${ }^{2}$ policies currently do not exist in Ukraine. Capital allowances are in the form of preferential depreciation rates for fixed assets, including buildings and constructions (for foreign and domestic investors). Income and capital gains tax relief for investors exist in the form of guarantees and benefits for foreign investors, an STS for SMEs, tax holidays for small companies (from January 2017 onward), and temporary tax benefits for some sectors (for example, information technology and aviation). There are value added tax (VAT)/customs duty exemptions for entities engaged in investment projects in 'priority industries', as defined by the Cabinet of Ministers of Ukraine. An entity operating in a priority industry may qualify for the incentives if the project has been approved by the government and meets specific legal requirements regarding the minimum amount of investment, number of new jobs created, and so on. The incentives include (a) an exemption from customs duties on the import of equipment for eligible projects, subject to specific approval from the Cabinet of Ministers of Ukraine (available until January 1, 2018), and (b) the ability to postpone payment of import VAT on imported equipment by issuing a VAT promissory note to be paid in cash within 60 days. A special economic zone (SEZ) was set up in the Autonomous Republic of Crimea and Sevastopol City in 2014, which granted tax breaks for their investments in the country, including full exemption from corporate income tax, individual income tax, VAT, excise tax, and environmental tax. Ukraine established 12 industrial parks in 2012, out of which only 4 were operational by 2016.

\footnotetext{
2 Patent box is a special regime that reduces taxes for revenues from intellectual property (IP), including revenues from products manufactured on the basis of IP.
} 
Attracting foreign direct investment (FDI) and invigorating investment promotion activities through various means have long been core government objectives. Some of the initiatives include the following: (a) foreign investors can benefit from specific tax provisions made available to SMEs; (b) enterprises with foreign investments are exempted from paying import duties on in-kind contributions made by foreign investors into the charter capital (except for goods for sale or use for purposes not directly related to business activities); (c) tax is not levied on income of foreign investors withheld at source in Ukraine, received under the production sharing agreement (PSA) with the Ukrainian authorities, which is paid by its permanent establishment.

Persistent political and macroeconomic instability has endangered promotion activities, and perhaps because of the instability, these initiatives have not been successful in achieving their desired goals. In addition, lack of systematic monitoring and evaluation exercises based on reliable data collection makes it difficult to assess the success of these policies.

Tax incentives for investment proved too costly from the perspective of the Ukrainian Ministry of Finance. Ensuring Ukraine's macroeconomic stability has become a major priority for the Ukrainian authorities to guarantee that the investor-friendly framework conditions are in place. To that end, the health of public finances, including stabilization of the country's public sector debt and fiscal consolidation, has been high on the agenda of Ukrainian policy makers. A number of measures, aimed at expanding the tax base through elimination of the most ineffective tax exemptions and privileges to increase tax revenues, have been undertaken during the past two years. In February 2015, pursuant to the conditionalities attached to the International Monetary Fund loans, the government further committed to eliminating tax exemptions. Administrative complexities and lack of transparency have been shown to be among the primary reasons for tax incentives to prove ineffective in Ukraine ${ }^{3}$ (Liakhovets 2014).

\footnotetext{
${ }^{3}$ http://politica-ua.com/nalogovaya-reforma-vyzov-dlya-ukrainy/; http://gazeta.zn.ua/finances/ukraina-nalogovo-Igotnyy-
} $\underline{\text { mazohizm- .html }}$ 
This section discusses the failures that occur in markets related to innovation activities and presents the economic justification of government involvement in R\&D and innovation.

\section{Characteristics of Innovative Activity}

$R \& D$ is a type of investment that is intended to generate future outputs. Similar to the way investment in physical capital generates output goods in the traditional model, R\&D generates knowledge capital, which can then be used as an input for production (Griliches 1979; Hall, Mairesse, and Mohnen 2010). Output production through innovative inputs can be thought of as a two-stage process, where investment in R\&D leads to an accumulation of knowledge in the first stage, followed by the second stage where the knowledge stock is used to produce tangible outputs. At the firm level, the first stage knowledge production can be imperfectly measured by the company's ownership of IP. The second stage is a traditional production function with innovation as an input to the production process (in a framework such as Crepon, Duguet, and Mairesse 1998).

From the perspective of a government that strives to achieve the socially optimal level of private investment in R\&D, there are important characteristics that distinguish R\&D from other types of investment: (a) knowledge is a public good, which, through spillovers, benefits more than just the investor in the R\&D that has generated this knowledge; (b) R\&D projects have highly uncertain outcomes; and (c) $R \& D$ projects are usually longer than projects for investment in physical capital. For example, the average time required for an R\&D project in the pharmaceuticals sector to develop a drug is around 9-10 years.

These characteristics identify two main market failures that result in the private sector's underinvestment problem in R\&D.

(a) Imperfect appropriability of knowledge as a public good. Knowledge spillovers contribute to the process of economic growth by facilitating advances in technology. Aghion and Howitt (1992) model economic growth as the result of a continuous process of creative destruction in a setting where inventors consider future innovations that will render their investment in R\&D obsolete and rely on well-functioning IP protection to allow them to reap monopoly profits from their investment.

Inventors of new products acknowledge that competitors have the potential to learn from their invention as soon as the product starts being commercially traded ('business-stealing', as in Tirole 1988, 399). Entrepreneurs are also well aware that future inventions may render their product obsolete, driving down all of its commercial value. In this environment, the private sector will invest less than the ideal amount in research and innovation (Arrow 1962). This justifies government intervention to ramp up private spending in R\&D.

Strengthening the IP protection system is one way to alleviate (but not eliminate) the inappropriability problem. The government may also choose to intervene using direct subsidies for the projects, which the government itself believes are the most beneficial for the society. Tax incentives, as an alternative, leave the decision regarding which project to pursue to the firms themselves, which may prove to be more efficient when the firms are more knowledgeable about the commercial prospects of their R\&D efforts.

The spillover effects discussed here occur mostly in 'technological fields'. For example, an invention that takes place in California in the area of semiconductors may have a positive effect in the technological 
advancement of a mobile phone that is developed in South Korea (Jaffe 1986). There is also some evidence for positive 'geographic spillovers', which is about the interaction between firms that are located close to each other or to a research institution. Colocated firms may benefit from the scientific work that is carried out in the neighboring firms or research institutions (Abramovsky and Simpson 2011; Bloom, Schankerman, and van Reenen 2013), and such interactions may offer a justification for policies that encourage clusters, but these are discussed later in this report, along with several caveats.

(b) Informational asymmetries and missing market for entrepreneurial finance. Informational asymmetries occur when one party to a transaction has access to relevant information and the other party does not. These informational asymmetries may discourage agents from engaging in potentially mutually beneficial transactions. In the field of innovation, the potential value of a newly invented product is usually unknown to outsiders and sometimes even to the inventors themselves.

One way in which informational asymmetries cause an obstacle is by generating financing constraints for innovators. Financing constraints emerge as a major obstacle not only to private R\&D spending, but also to investments in physical capital. In the absence of financing constraints, firms' demand for investment should depend on the profitable opportunities that they face. In the 'unconstrained' scenario, firms invest up to the point where the marginal project breaks even (Hall and Jorgenson 1967; Jorgenson 1963). In the presence of financing constraints, firms risk missing out on positive net present value (NPV) projects, generating inefficiencies in the market.

The high cost of external finance arises from asymmetric information between suppliers of finance and the firms. Because the lenders and potential equity holders do not have full information about the business prospects of firms, they put a premium on the cost of financing options made available to them. Of course, the issue is much less severe for firms operating in traditional sectors and for incumbent firms. Financiers have more widely available knowledge about these typically large and established firms to 'trust' them with various financing options. Such firms can also use their existing fixed assets as collateral to borrow from banks or go public to raise equity.

\section{Figure 2. Demonstration of Liquidity Constraints through the Hierarchy of Finance Models}

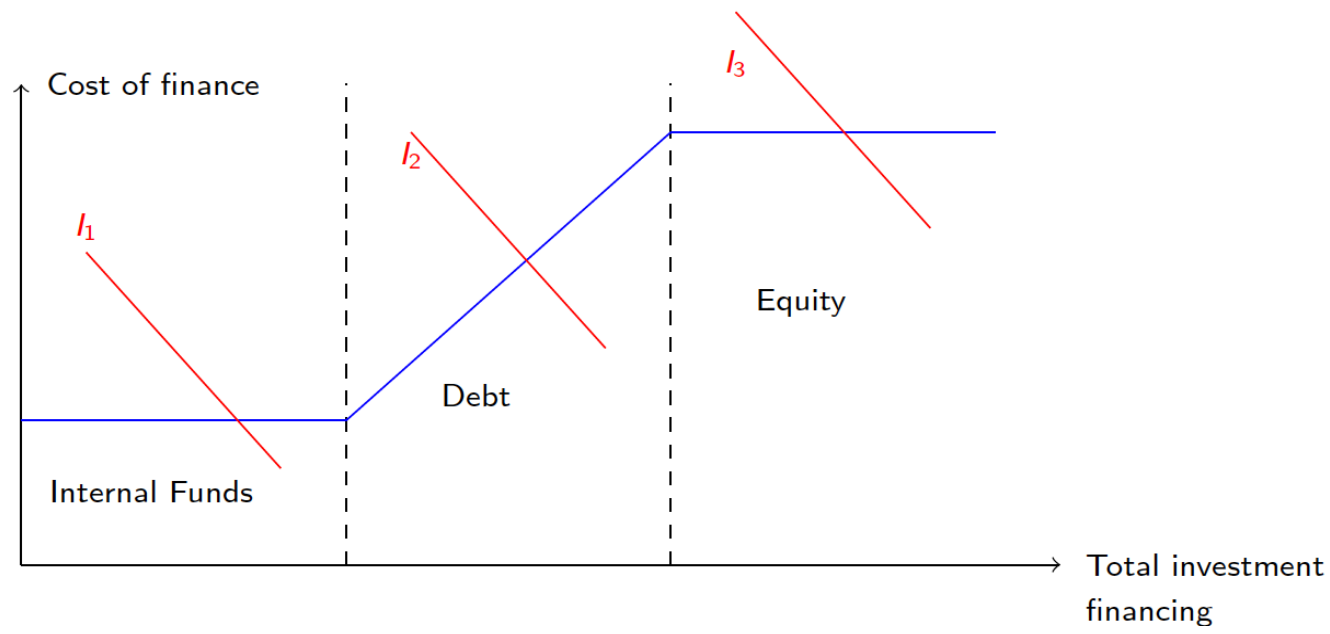

Source: Based on the ideas in Fazzari, Hubbard, \& Petersen (1988); Myers \& Majluf (1984). 
Figure 2 demonstrates the shift in investment demand in the presence of financing constraints. The three investment demand schedules characterize the equilibria in different regions-investment schedule $I_{1}$ takes place in the unconstrained region. To take on the projects that occur along the schedules $I_{2}$ and $I_{3}$, the firm needs to raise funds from external sources. When the firm uses internal funds, the least costly option, it invests up to the point where it starts making zero gains from the next available project. External funds are costly, and therefore the firm may have to forego profitable investment projects if it cannot finance them. In the figure, a windfall increase in the firm's cash flow would shift the cost curve to the right, enabling some positive NPV projects to be taken on by the constrained firms. A tax incentive may work toward achieving such shifts in companies' marginal cost of financing.

In the case of innovative start-up firms, traditional sources of bank financing break down, as these companies usually do not have a stock of fixed assets to offer to the banks as collateral. Even for more advanced knowledge-based start-ups with some IP ownership, the value of the patent or other intangible asset is unclear to the lender, especially because banks are not equipped to assess the value of innovative start-ups.

In a more advanced setting, where angel investors and venture capital (VC) funds are readily available, the informational asymmetry is partly offset as providers of equity financing engage with the businesses in which they invest. In the case of some angel investors, the investors directly become involved in the running of the business or mentor the entrepreneurs, or many venture funds diversify their risk by investing in multiple ventures (Hall and Lerner 2010).

The Silicon Valley model of a lively VC industry does not exist in most countries, and the problem is more severe in developing countries. The absence of providers of external finance to constrained firms therefore characterizes the 'missing market' problem, which is the topic of this section. Governments that are faced with this problem have the option of supporting private investors in new ventures and establishing fund-of-funds structures.

VC funds profit from successful exits, which means that their business model relies on future opportunities for initial public offerings or acquisitions of the ventures in which they invest. The potential for future public trading of companies then relies on a deep and well-functioning financial market, which is usually lacking in the developing country contexts. Figure 3 demonstrates the difficulty of increasing the availability of venture funding for underdeveloped markets in the absence of any intervention.

Figure 3. The Cycle of Insufficient Equity Financing in Developing Countries

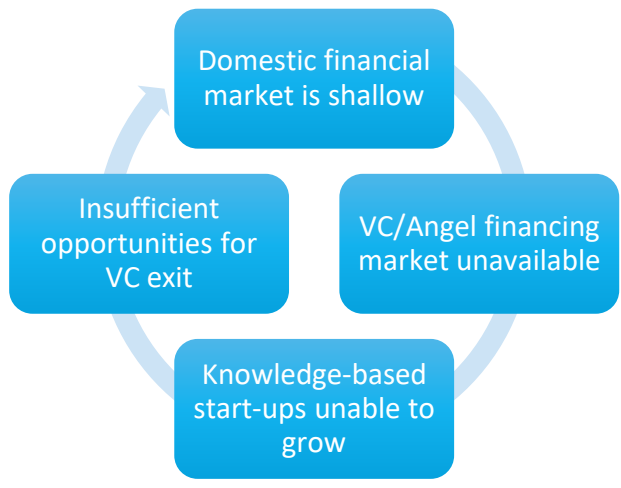

In addition to the market failures discussed earlier, there are institutional failures that may hinder the functioning of countries' STI infrastructures. 


\section{Government's Objective for Intervention}

Characteristics of innovation activities that have been outlined in the preceding section suggest that there is a role for government intervention in overcoming the market failures in research and innovation. However, the government has to define its objectives clearly before making the decision to channel public funds.

For example, if the objective is to attract FDI to facilitate local economic activity and jobs at the local level, then reforms aimed at improving the ease of doing business may prove useful. On the other hand, if domestic job creation is the priority, then the government may focus on incentive mechanisms that help firms hire high-skilled employees, such as technicians, scientists, and engineers. Such policies include waivers of employees' social security contributions or payroll taxes for R\&D employees (discussed in the next section).

An important objective may be the facilitation of knowledge-based start-ups. Achieving this requires policy measures to address the intersection of market failures facing both young firms and innovative firms. As discussed in the preceding section, knowledge-based start-ups will only invest if they are able to overcome financing constraints and if they are able to commercialize their ideas.

A set of policy instruments are available to achieve these objectives, as shown in table 1. Options can be broadly categorized as follows: (a) direct financial support, including equity financing, loan guarantees and reduced interest rates, subsidies, vouchers, grants, and matching grants; (b) indirect financial support, including tax incentives for innovation activities; and (c) nonfinancial support, including innovative public procurement, prizes and awards, infrastructure investments such as incubators, science parks, technology transfer offices, advisory, extension, and training services, regulation and standards for innovation, collaborative and systemic policies for innovation, information, advocacy, and voluntary initiatives.

\begin{tabular}{|c|c|}
\hline Category & Type of Support/Instrument \\
\hline \multirow[t]{4}{*}{ Direct financial support } & Equity finance \\
\hline & Loan guarantees and reduced interest rates \\
\hline & Subsidies/vouchers \\
\hline & Grants/matching grants \\
\hline Indirect financial support & Tax incentives for innovation \\
\hline \multirow[t]{7}{*}{ Nonfinancial support } & Public procurement \\
\hline & Prizes and awards \\
\hline & Infrastructure (incubators, parks, technology transfer offices) \\
\hline & Advisory, extension, and training services \\
\hline & Regulation and standards for innovation \\
\hline & Collaborative, network, and systemic policies for innovation \\
\hline & Information, advocacy, and voluntary \\
\hline
\end{tabular}

Source: "Innovation policy instrument guide," Innovation in Developing Countries, World Bank (2017). 


\section{Fiscal Incentive Schemes for Science, Technology, and Innovation}

This section discusses fiscal incentives that can be used to achieve particular objectives, along with good practice examples.

Fiscal incentives aim to address the market failures discussed in the previous section. Instead of channeling funds directly to firms, governments may use tax incentives to maintain the efficiency of the free market decision-making mechanisms, while alleviating companies' financing constraints. Beneficiaries of tax incentives are flexible in choosing projects and the most profitable investments in $R \& D$, as beneficiaries tend to be more knowledgeable about their own projects than public officials. Fiscal incentives have another attractive feature for the policy makers, that is, the ease of administration. The policy makers do not need expert panels to assess which R\&D project promises to be more successful or more beneficial for the society. An important point is that tax incentives tend to be more transparent and less distorting than direct measures, which can be also influenced by powerful interested parties (World Bank 2017).

The following are additional reasons tax incentives can support private R\&D (World Bank 2017):

- Motivate firms to invest in R\&D by reducing their tax burden and the cost of R\&D.

- Ease the constraints for innovative start-ups and small firms by strengthening their financial capacity.

- Support collaborative investments in R\&D between private firms and research organizations.

Partly owing to these attractive features, fiscal incentive schemes for STI have become increasingly popular around the world. This report discusses the most commonly used fiscal incentive schemes and a corresponding good practice (see table 2). The examples were selected for demonstrative purposes and do not suggest applicability in the current Ukrainian environment.

\begin{tabular}{rll} 
Table 2. Fiscal Incentives and Selected Country Examples \\
\multicolumn{2}{c}{ STI Fiscal Incentives } \\
\hline 1. & R\&D tax incentives & France R\&D tax incentive system \\
\hline 2. & Capital allowances & Bonus depreciation in United States \\
\hline 3. & $\begin{array}{l}\text { Income and capital gains tax reliefs } \\
\text { for investors }\end{array}$ & $\begin{array}{l}\text { Venture Capital Trust (VCT), Enterprise Investment Scheme (EIS), } \\
\text { Seed Enterprise Investment Scheme (SEIS) in United Kingdom }\end{array}$ \\
\hline 4. & Incentives associated with SEZs & Zhongguancun Science Park (ZSP) in China \\
\hline 5. & $\begin{array}{l}\text { VAT or customs duty exemptions for } \\
\text { imported inputs }\end{array}$ & Chile VAT exemptions \\
\hline 6. & Patent box regimes & In the making \\
\hline
\end{tabular}

\section{R\&D Tax Incentives}

R\&D tax incentives are a class of policy tools intended to increase businesses' R\&D spending by (a) decreasing the user cost of R\&D capital and (b) enabling access to finance for firms, thereby addressing the two market failures discussed earlier. 
On average, in advanced economies, roughly 50 percent of aggregate R\&D spending is on salaries and wages of personnel related to R\&D activities. Salaries and wages are normally 100 percent expensed before calculating taxable income, unless there are restrictions related to capitalization of R\&D. The remaining 50 percent of $R \& D$ expenditures can be roughly split into 40 percent for supplies and 10 percent for the acquisition of capital goods used in R\&D. The large weight of current expenditure items in R\&D makes it a special type of investment for tax purposes.

R\&D tax incentives take many forms, including (a) tax credits, (b) enhanced/super-deductions, (c) cash refunds for loss-making firms, (d) exemptions of payroll taxes or social security contributions of R\&D personnel, and (e) accelerated depreciation of machinery and equipment used in R\&D. In the last decade, many countries started adopting tax incentives for R\&D, and many countries with existing schemes switched to more generous incentives (Hall and van Reenen 2000).

Figure 4 presents a ranking of countries included in the OECD's Science, Technology, and Industry Scoreboard by the generosity of R\&D tax incentives. The design of R\&D tax incentive schemes is more important though than their generosity-Figure 4 reveals two of the dimensions in which policy design can be nuanced: (a) differential treatment of SMEs as opposed to large companies and (b) treatment of loss-making companies. Regarding the latter, some countries provide cash refunds or carryforwards and carrybacks of the tax incentives to allow loss makers to benefit, as well as profitable companies. In the figure, the difference between the diamonds and the bars demonstrates that countries design policies to favor profitable firms and, in some cases, completely disregard loss makers by not even allowing for the carryforward of the tax incentives.

In Brazil, for example, the R\&D tax incentive scheme is in the form of super-deductions, but neither SMEs nor large companies can benefit from them when in a loss-making position. Many young and innovative firms incur losses for extended periods, and some of them have to forego positive NPV investment opportunities due to credit constraints. One way to alleviate such credit constraints is by offering full or partial cash refunds to loss-making firms. France, Canada, and the United Kingdom are examples of countries that offer cash refunds to loss-making businesses within their R\&D tax incentive schemes. 


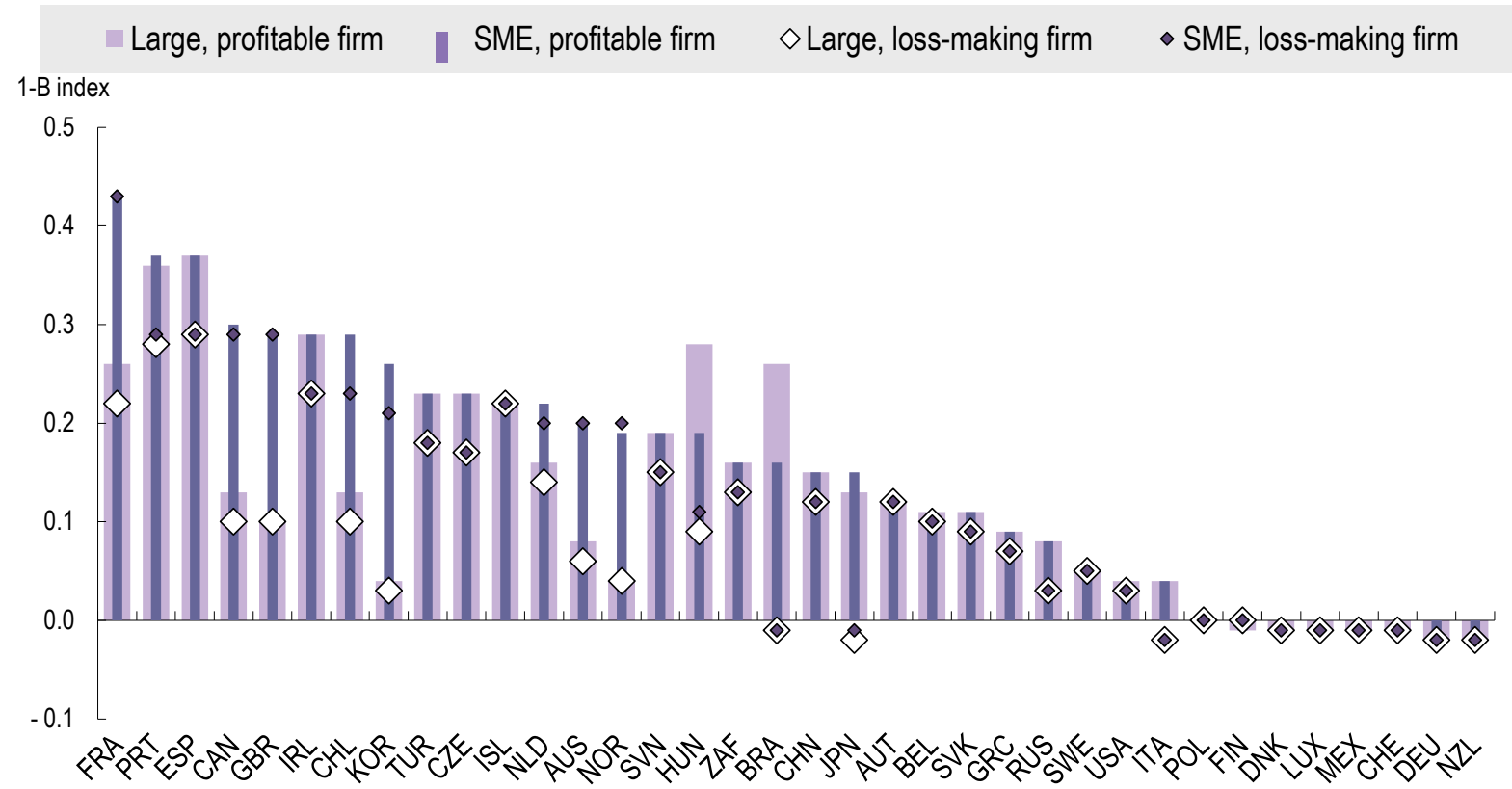

Source: OECD Science, Technology and Industry Scoreboard (2015). Tax subsidy rates on R\&D expenditures. The 'B-index measure' captures the tax component of the user cost of R\&D capital. Further information can be found in Correa and Guceri 2013.

Another design consideration in the case of R\&D tax incentives is the decision regarding the base level of qualifying R\&D spending on which to calculate any credits or deductions. Two main designs include (a) volume-based schemes where the total $R \& D$ in a given year is taken as the base and (b) incremental schemes where the increase over a reference year (for example, the previous year or an average of multiple years) is taken as the basis for providing incentives.

Empirical studies have found that incremental schemes resulted in firms strategizing around the timing of their R\&D spending to maximize the benefits and thus have favored volume-based schemes. Some countries have experimented with different schemes. One prevalent example is France, which completely abolished its incremental scheme and moved to provide generous, refundable volume-based R\&D tax credits to businesses. Overall, evaluation studies find a positive effect of tax incentives.

\section{Table 3. Results of a Few Academic Studies on the Effectiveness of Tax Incentives}

Study

Bloom, Griffith, and van Reenen 2002

Agrawal, Rosell, and Simcoe 2014

Rao 2016

Guceri and Liu 2017

Mulkay and Mairesse2013

Lokshin and Mohnen 2011

Source: Guceri 2016.
Increase in R\&D for $10 \%$ Drop in User Cost

Finally, R\&D tax incentives require additional capacity building within the tax authority. In many cases, 'additional capacity' takes the form of specialist units that both provide guidance to claimants and carry 
out random audits to verify that the spending subject to the benefits is genuine R\&D. The problem of companies reclassifying ordinary spending as R\&D is known in the literature as the 'relabeling' problem. Even though there is some anecdotal evidence supporting the presence of the relabeling problem, quantitative studies on developed country examples do not seem to suggest that the extent of the issue is very large.

\section{Example: France}

Design considerations are crucial for success in R\&D tax incentive systems. The French R\&D tax incentive system has undergone many changes since its inception decades earlier. The scheme started as an incremental policy, which was then gradually phased into a volume-based scheme in the 2000s. France's support policy framework for R\&D currently relies on a mix of direct subsidies and refundable tax incentives, which constitute around 70 percent of total public support for business R\&D (OECD 2017a; OECD-NESTI 2013).

France's success story is about the realization of the inefficiencies within the support mechanism and transitioning to a system that is simpler and more effective over time. This was owing to the many impact evaluation studies that researchers conducted using firm-level data on beneficiaries. The transition from an incremental to a volume-based scheme happened gradually, with the government announcing its longterm plans well in advance to reduce policy uncertainty. The introduction of refundability has also allowed loss-making firms to benefit from the policy.

The most significant changes in France's R\&D tax incentive system are summarized in Figure 5 . The important aspect of these changes is the emphasis on simplification over time.

Many countries, which started implementing R\&D tax incentive schemes in the 2000s, actually introduced simple policies such as the one that France has now, without having needed to go through the learning process that France experienced earlier on.

\section{Figure 5. Time Line of Significant Events in France's R\&D Tax Incentive System}

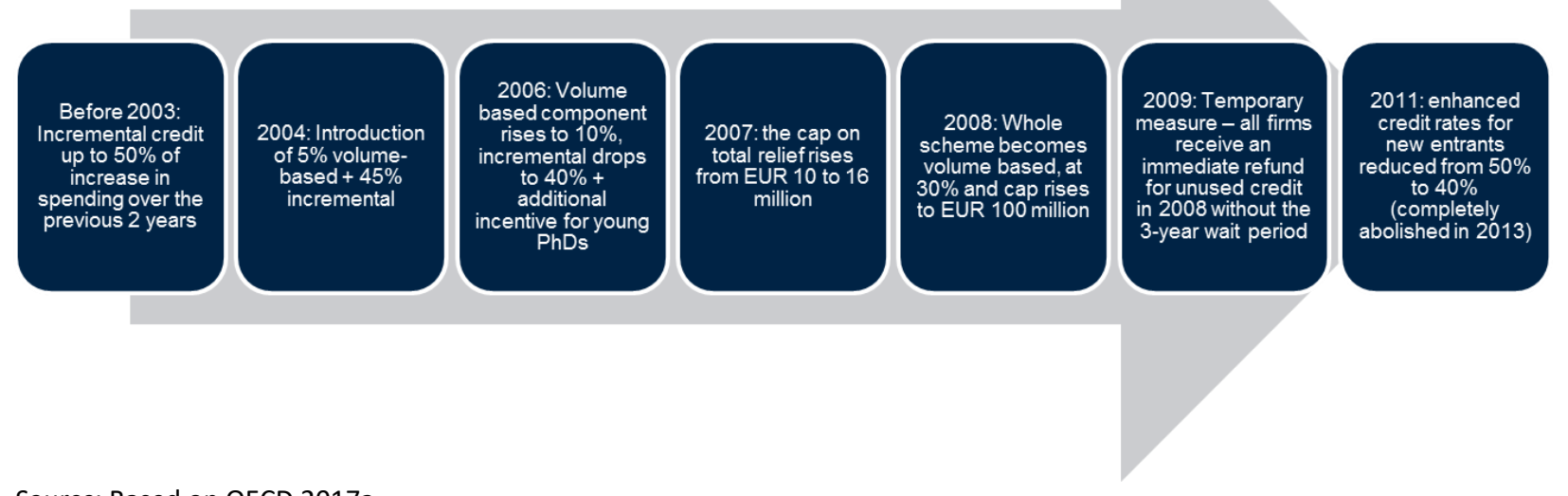

Source: Based on OECD 2017a. 


\section{Capital Allowances}

Capital allowances are intended to promote the accumulation of physical capital by firms with the expectation that new machinery and equipment will enable the adoption of productivity enhancing process innovations. Normally, capital goods are not immediately expensed from taxable income upon acquisition. Firms are only allowed to write down a portion of the cost of acquiring the capital good, based on the allowed accounting depreciation rates for the particular type of good. Capital allowances offer a more generous tax treatment of capital goods and define the amount that businesses can deduct from their taxable income.

When intended to promote SMEs' acquisition of new machinery and equipment, these incentives may take the form of full expensing in the first year up to a limit and then writing down the remaining amount based on predetermined depreciation rules. For example, in the case of United States' 'bonus depreciation' scheme, eligible capital goods can be depreciated by an additional 50 percent in the first year of acquisition.

As in the case of R\&D tax incentives, the policy design needs to consider companies incurring tax losses. Loss carrybacks and carryforwards allow firms to benefit from the tax incentives in the year of loss, if the firm has sufficient prior year profits in the case of a carryback or if it switches to profit relatively soon in the case of a carryforward. Some countries allow these losses to be offset against the profits of companies within the same enterprise group or under common ownership.

\section{Example: United States}

The bonus depreciation in the United States applies to expenses on investment goods and allows firms to apply preferential depreciation rates to encourage capital expenditure and technology upgrading. Bonus depreciation allows firms to deduct from the taxable profit an additional 50 percent of the cost of capital goods that qualify for the policy in the first year, in addition to the normal depreciation allowance available. The main caveat in the United States is that such policies are introduced temporarily, which creates some uncertainty about when the policy may cease to be implemented.

\begin{tabular}{|c|c|c|c|c|c|c|}
\hline Year & 0 & 1 & 2 & 3 & 4 & 5 \\
\hline \multicolumn{7}{|c|}{ Normal Depreciation } \\
\hline Deductions (in thousands) & 200 & 320 & 192 & 115 & 115 & 58 \\
\hline Tax gain (at 35\% rate) & 70 & 112 & 67 & 40 & 40 & 20 \\
\hline \multicolumn{7}{|c|}{ Bonus Depreciation } \\
\hline Deductions (in thousands) & 600 & 160 & 96 & 58 & 58 & 29 \\
\hline Tax gain (at 35\% rate) & 210 & 56 & 33 & 20 & 20 & 10 \\
\hline
\end{tabular}

Table 4 presents a hypothetical scenario in which a firm acquires US\$1 million in computers. The normal depreciation schedule deducts less in the initial year, with the tax gain maximized in the second year, whereas the 50 percent bonus depreciation allows the deduction of three times as much of the cost in the first year, with the tax gain sharply declining from the second year onward.

Reliable, high-quality data are crucial for impact evaluation. There are many studies that explore the impact of the bonus depreciation scheme. A recent paper by Zwick and Mahon (2017) finds that firms respond strongly to depreciation incentives. Firms respond strongly if they use the benefits immediately, 
and they do not if they are loss making and have to carry forward the benefit. In a study that uses U.K. data, Maffini, Xing, and Devereux (2016) find a strong response in the United Kingdom of capital allowances as well.

Maffini, Xing, and Devereux (2016) show that the firms are motivated to minimize tax liability by bunching below the thresholds for eligibility; nevertheless, the authors find positive effects on investment even controlling for this bunching.

\section{Figure 6. Investment Responses by the Recipients of Bonus Depreciation}

Panel A. Intensive margin: bonus I

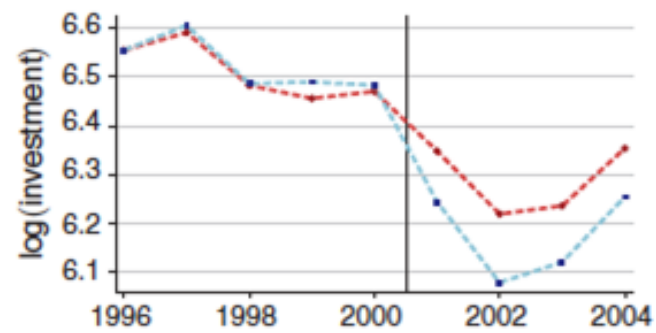

Panel C. Extensive margin: bonus I

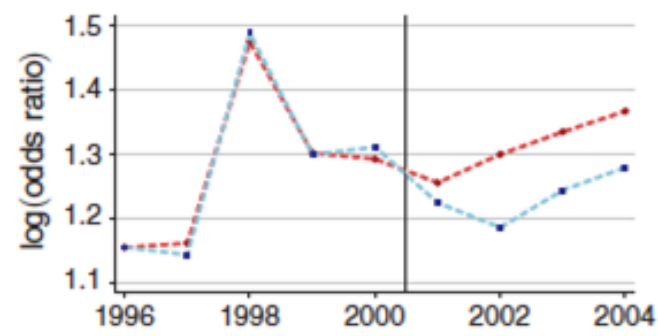

Panel B. Intensive margin: bonus II

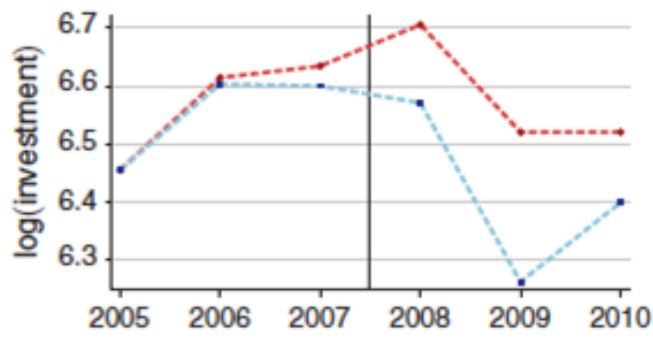

Panel D. Extensive margin: bonus II

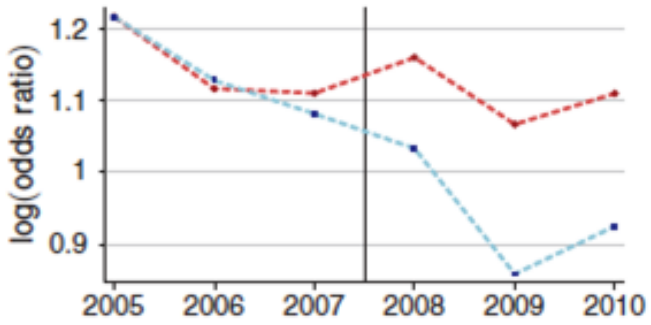

--.-- Treatment group (long duration industries)

--- Control group (short duration industries)

Source: Zwick and Mahon 2017.

\section{Income and Capital Gains Tax Relief for Investors}

Some countries allow investors in SMEs or new ventures relief on income tax. This may be channeled through 'VCTs' or be directly provided to individual investors. These funds help investors hedge risks of investing in start-ups and SMEs. Another advantage for the investor is that it has a direct cost reduction effect, making it a desirable support mechanism for VCs. These types of policies therefore address the second market failure discussed earlier, by facilitating the development or deepening of entrepreneurial finance. The caveat with these kinds of regimes is that wealthy individuals may approach it as a tax avoidance tool.

\section{Example: The United Kingdom}

The United Kingdom operates three schemes at the same time to offer tax incentives for investors in companies that qualify for the scheme. To qualify, companies need to have fewer than 250 employees and less than $£ 15$ million of gross assets (and there are further restrictions regarding the group structure 
of companies):

(a) VCTs operate through VCs that are publicly listed. Investors can buy shares in the trust and access generous income tax reliefs as well as relief on capital gains when the shares are sold (at the same time investors have to pay management fees to the trust).

(b) The EIS allows individual investors to benefit from generous income tax reliefs and relief on capital gains tax when they invest in companies that qualify for the scheme.

(c) The SEIS applies a more generous version of the EIS for investors in early-stage companies.

Evidence on the effectiveness of income tax reliefs for wealthy investors is mixed. Anecdotal evidence suggests that wealthy individuals perceive these schemes as tax avoidance strategies rather than having a genuine interest in nurturing new businesses. At the same time, official statistics suggest that the U.K. EIS and SEIS schemes have steadily raised increasing amounts of funds for SMEs in recent years, despite a temporary drop during the global liquidity crisis of 2008-2010. ${ }^{4}$ VCTs are also believed to have helped in deepening the market for entrepreneurial finance.

The EIS was introduced in 1994, and the SEIS in 2012. Since the start of the EIS, 22,900 companies have received investment through the scheme and $£ 12.2$ billion of funds have been raised. ${ }^{5}$ In 2013/14, 2,710 companies raised $£ 1,457$ million of funds under the EIS, and almost 1,700 companies raised funds under the SEIS for the first time in $2013 / 14$, representing $f 148$ million in investment.

The impact of the EIS and SEIS has been found to be substantial for entrepreneurial investment of small firms, but not for medium-size firms (Gonzales-Uribe and Paravisini 2016).

\section{Incentives Associated with SEZs}

SEZs are areas allocated for certain activities and allow qualified firms that locate within the zone to enjoy tax exemptions and, in some cases, exemption from certain administrative requirements. These aim to facilitate gains of agglomeration, including knowledge spillover benefits in the case of knowledgeintensive industries and common use of physical infrastructure in the case of more traditional industries. Promotion of knowledge-based start-ups could also be an objective of establishing science parks.

SEZs may allow many different types of fiscal incentives, including corporate income tax benefits, capital allowances, sales/excise tax benefits, land tax exemptions, VAT exemptions, tax holidays, dividend tax exemptions, and exemptions of payroll taxes. However, the main idea should be to provide common infrastructure and interaction, and not only a zone for tax benefits, which can be provided independently of location.

Special territories are popular worldwide. In 2015, there were about 4,500 SEZs in 140 countries employing around 66 million people. For example, in the Association of Southeast Asian Nations (ASEAN),

\footnotetext{
${ }^{4}$ HM Revenue and Customs, July 2015, Commentary on EIS and SEIS Official Statistics.

${ }^{5}$ HM Revenue and Customs July 2015, Commentary on EIS and SEIS Official Statistics.
} 
there are 893 industrial parks, 84 SEZs, two eco-industrial parks, 25 technology parks, and 1 innovation district. $^{6}$

An unusual form of special territories is tax increment finance districts, used in the United States. In these districts, the area's incremental tax revenue (or the increase in property tax revenues due to higher value) remains with the district to pay off redevelopment costs or to pay for more investments (Francis 2016).

Incentives may be offered by national, regional, or local authorities, with the goal to boost economic development of certain territories through attracting FDI and domestic investment, stimulating growth of local companies, supporting $R \& D$ and innovation, developing specific sectors, enhancing the local workforce quality, increasing export, solving unemployment problems, and developing transborder cooperation. Such territories may be also used as a platform for testing new policies that may then be expanded across the country. ${ }^{7}$

Policy prioritization, through a comprehensive approach, is critical when planning an innovation policy and establishing science and technology parks as part of a wider policy framework. Targeted incentives may include separate sets of short- and long-term policies, and fiscal and direct financial support mechanisms are only one way through which science and technology parks support innovation activities (a more detailed characterization of financial and nonfinancial policies within the context of SEZs can be found in the World Bank/InfoDev report titled 'International Good Practice for Establishment of Sustainable IT Parks' [PriceWaterhouseCoopers 2008]).

SEZ performance is difficult to measure, and promising results from different practices around the world may be misleading. Usually, successful zones are a result of positive spillovers, and the location of the SEZs cannot be disentangled from economic agglomeration forces. However, fiscal benefits for SEZ tenants may lead to increases in land prices, which in turn may reduce the effect of financial benefits. Many SEZs get built and then fail to attract many innovative firms. It is also common for firms to enjoy the financial benefits without creating much employment or other activities. Nevertheless, there are also a significant number of success stories.

Turkey is one example where the government initially opted for tying R\&D tax benefits to residence in technoparks. This resulted in an increase in land prices and caused distortions to firm behavior. The technopark initiative in Turkey, which started in 2001, led to companies having to pay large sums as rent and the employees finding 'alternative arrangements' to fulfil a work schedule from 9 a.m. to 6 p.m. The tax incentives were related to the number of R\&D personnel; the turnstiles and cameras at the entrances of technopark office areas meant that the employees, whose salaries were subjected to tax benefits, had to enter and leave the offices at a set time. This was important for their salaries to qualify for the tax and social security contribution benefits. Considering that the average tech start-up employee does not necessarily work in an office between 9 a.m. and 6 p.m., Turkish technopark residents started to encounter difficulties in benefiting from the tax incentives. Consultations with businesses later on led the Turkish government to disentangle most of the tax benefits from technopark residency. Currently, technoparks are predominantly used to facilitate university-industry collaborations, host incubators, and provide advisory services and infrastructure to tech start-ups. Additional discussion of the Turkish and other countries' experiences with SEZs is available in the appendix.

\footnotetext{
${ }^{6}$ Economic Zones in the ASEAN. United Nations Industrial Development Organization (UNIDO) country office in Vietnam, August 2015.

${ }^{7}$ Economic Zones in the ASEAN. UNIDO Country office in Vietnam, August 2015. 


\section{Example: Zhongguancun Science Park, China}

ZSP has the clear objectives of advancing economic development through promoting high-tech industries, creating employment, and establishing an STI base. In 1991, the first incubator in ZSP was established, followed by two science parks in 1992. A few years later, ZSP was classified as a single zone with multiple parks within it. The first annual computer fair took place in 1997, and an Overseas Students Pioneer Park was established within ZSP in 1998. In 1999, the ZSP Management Committee started to be formed (PriceWaterhouseCoopers 2008).

ZSP facilities are funded by the government and managed by the ZSP Management Committee, which comprises nominated members of different government bodies. Major services offered by the Management Committee include land use and facilities planning, investment services, managing employment, legal, and accounting advice, and environmental protection. The seven parks within ZSP have around 12,000 tenants, with 68 percent operating in the IT sector. Domestic VCs are available and they operate in ZSP, but PriceWaterhouseCoopers 2008 finds that these are biased toward larger firms.

ZSP has very strong links with the top research centers that are neighboring the park. These include more than 200 research institutions and laboratories of the Chinese Academy of Science and the Chinese Academy of Engineering, along with top Beijing universities. The universities provide high-quality graduates to work in the companies that are located within the park.

One concern about infrastructure in ZSP is the increasing land price and property rentals.

ZSP provides R\&D tax incentives to firms located in ZSP, in addition to those provided by the government regardless of firm location. It is important, nevertheless, to acknowledge that the tax incentives are not the only attractive feature of the park. The whole ecosystem generated around good infrastructure, human capital, and proximity to research institutions make ZSP an attractive location for high-tech companies, especially those operating in the IT sector.

\section{VAT or Customs Duty Exemptions for Imported Inputs}

As discussed earlier, many process innovations or technology upgrades to production equipment take place in different countries around the world. To facilitate technology adoption, many governments allow reduced rates or exemptions of import VAT for goods that are used in companies' businesses. These goods may range from software to heavy machinery, depending on the government's objectives for implementing the particular regime.

Reduced tariffs or customs duty for capital goods may lead to lower production distortions. Regarding a VAT exemption, however, there may be repercussions for the rest of the production chain and VAT exemptions and therefore may be less effective or distortionary at different levels in the production chain (IMF 2015; Ebrill et al. 2001).

\section{Example: Chile}

In Chile, a flat VAT rate of 19 percent is in place. However, projects that are defined as 'investment projects' aligned with national interests under the Foreign Investment Statute (Decree Law 600) can obtain an exemption of the VAT on their imported inputs. The Chilean VAT exemption is strictly targeted 
toward foreign investors. This policy was adopted as part of a wider set of policies for attracting foreign investment, so the aim of this policy is not technology adoption.

The Chilean authorities require that FDI must have generated income for at least 12 months leading up to the import of the capital good subject to the exemption. FDI is defined as the transfer of foreign capital or assets into Chile of an amount greater than US\$5 million and materialized through effective cash flows of foreign currency, tangible assets, reinvestments of profit, capitalization of loans, different forms of technology, or loans related to foreign investments from related companies. ${ }^{8}$

Such a policy may be successful in attracting foreign investment but at the same time discourage local investors, and therefore, design details are extremely important to minimize any distortions that such a policy may introduce.

\section{Patent Box Regimes}

Countries have started to rethink the tax treatment of gains from IP ownership in the recent years. Even though nations such as France and Ireland started to allow reduced tax rates for rents on IP in the 1970s, many European countries, and others such as China, started implementing preferential rates on profits made on patents during the late 2000s (Alstadsaeter et al. 2015). For example, in China, patent income is subject to a 10-percentage point lower tax rate relative to the headline corporate tax rate. In many European countries, roughly half the headline corporate tax rate is used as the preferential rate for patent income (for example, 10.3 percent in Hungary relative to the main rate of 20.6 percent).

While R\&D tax incentives are termed 'front-end support schemes', patent box regimes provide 'back end support', as they allow the companies that have previously performed R\&D and obtained certain types of IP to benefit from preferential corporation tax rates. In the early years of implementation of these regimes, countries such as Switzerland or Hungary allowed firms to just transfer their IP to the low tax jurisdiction and pay very low taxes on the gains from the ownership of such IP. Similar to front-end support schemes, the idea is to reduce the R\&D user cost of capital, this time by lowering the tax rate that applies on rents that accrue from the ownership of IP.

\section{Example: Base Erosion and Profit Shifting Process Recommendations}

Patent box policies are rather new (except earlier versions implemented by some countries, such as France and Ireland), and there is no clear evidence in the literature that these incentives have worked to facilitate R\&D investment or productivity in the jurisdictions in which they have been introduced in the past.

The ongoing Base Erosion and Profit Shifting (BEPS) agenda of the OECD and the G-20 has identified a mere transfer of patents to a low tax jurisdiction as a harmful tax practice. ${ }^{9}$ The BEPS Project Action 5 emphasizes the importance of aligning tax benefits with the location of real R\&D activities. Under the OECD recommendations, the incentives provided under patent box regimes should converge in principle toward front-end R\&D tax incentives. Under these principles, acquired IP cannot be incentivized. These schemes are currently experimental, and initial estimates suggest that the non-nexus compliant regimes

\footnotetext{
${ }^{8}$ Source: KPMG, 2015, retrieved from https://home.kpmg.com/xx/en/home/insights/2015/06/chile-new-foreign-investmentstatute.html

${ }_{9}^{9}$ OECD/G-20 Base Erosion and Profit Shifting Project Action 5: Agreement on Modified Nexus Approach for IP Regimes available at https://www.oecd.org/ctp/beps-action-5-agreement-on-modified-nexus-approach-for-ip-regimes.pdf.
} 
(the regimes where the patent box benefits are not tied to R\&D performed in the particular jurisdiction) lead to increases in patent registrations in low tax jurisdictions, without substantial innovation activities (Griffith, Miller, and O'Connell 2014). For the time being, until further evaluation data are available, this report does not recommend implementation of a patent box policy in Ukraine. 
The good practice examples in this report have all been implemented as part of a broader agenda of strengthening the science and technology base of the country. Each of the policies in isolation would not have been sufficient to achieve the set objectives of the government.

Administrative inefficiencies may render any policy initiative ineffective. These may arise from low state capacity, corruption, or the lack of resources to implement rather complex policies. In the field of STI, specialist knowledge may be required of government officials. For example, revenue authorities, whose job is to collect taxes, usually administer R\&D tax credits. This makes the revenue authority the responsible entity for ensuring that expenditure that qualifies for R\&D tax credits is legitimate. Before claiming any R\&D tax credits, firms may have questions about whether or not their activities qualify. After claiming R\&D tax credits, audits may be required to ensure that the firms are complying with the qualification rules. In either case, the revenue authority may find itself in a position where it has to comment about the technical aspects of an R\&D project.

Many countries address the issue of administrative oversight of R\&D tax credits by establishing specialist units within the revenue authority. Another option is to have external control over the process through the relevant institution responsible for the private sector's science and technology projects. Both options are costly, and the latter may result in coordination problems between the entities involved.

Targeted initiatives may have some unintended consequences. In the case of technology and science parks, these negative externalities may be caused by (a) impediments to competition (non-technology development zone companies become less competitive), (b) increases in land prices and the associated office rental rates offsetting the monetary benefits of the park, and (c) distortions to resident companies' behavior as they try to maximize monetary benefits attached to residency in the park. Some examples are discussed in the relevant section.

Ex ante cost-benefit analyses, monitoring during implementation, and ex post impact evaluation are important to understand the pros and cons of policy design. The French R\&D tax incentive scheme is a good example of how monitoring and evaluation can lead to improvements. In this regard, reliable and systematic data collection for the private sector's R\&D spending enables such analyses.

A preliminary step before considering fiscal incentives for R\&D is to improve the investment climate by strengthening policy predictability, mitigating corruption and state capture, overcoming the political risks, and reducing the cost of doing business. Significant red tape and other costs of entry impede young and innovative start-ups from flourishing. Many studies highlight the importance of the investment climate for innovation. A survey of investors in southeast Europe shows that strategic investors consider tax factors as only one of the obstacles to investment (accounting for only 24 percent) (OECD 2017b). Investors reported that the key tax-related impediments are the instability and the unpredictability of the tax system. Investors either did not take tax incentives into account or reported negative effects of such incentives as they increase the complexity of the tax system. Nontransparent tax incentive regimes and corrupt officials have been reported to further complicate the investment climate.

The investment climate is especially crucial for determining the effectiveness of incentives in attracting FDI. Although lowering effective tax rates helps boost FDI, the effect is much stronger for countries with a good investment climate. Surveys of investors in Jordan, Mozambique, Nicaragua, and Serbia found that exporters consider investment incentives to be very important, while most non-exporters do not rank tax 
incentives among their top reasons for investing. Survey evidence also shows that some investors spent considerable time on understanding qualifying incentives, implying that these special benefits also impose costs (James 2013). 


\section{Concluding Remarks and Policy Recommendations}

The government's main objective-as well as the intermediate targets that lead to it-is an important consideration in deciding on the most suitable fiscal policy instruments in the field of STI. Table 5 presents an assessment of various policy options listed in this report in terms of their strength in leading to intermediate targets, as provided in the columns of the table.

The intricate details in the design of the policy are another important consideration as they are instrumental in the success of the policy toward achieving the government's targets. Some such targets are presented in the columns of Table 5 (facilitating technology transfer, increasing private R\&D, promoting technology adoption, and attracting FDI). A few examples of such design issues are helpful in summarizing their importance. As indicated earlier, an R\&D tax incentive policy is effective for smaller and younger firms only if they allow loss-making companies to benefit from the scheme in some way. Currently, there is not enough evidence on patent box regimes to suggest that they are effective in stimulating additional $R \& D$, but a scheme that ties the incentive to R\&D activity taking place within Ukraine would be superior to allowing any patent holder with patents registered in Ukraine to benefit. Science parks may work toward facilitating knowledge spillovers across colocated firms or research institutes/universities and the science parks. Geographic proximity may enable common facilities such as technology transfer offices to provide timely support for commercialization of spin-off companies. On the other hand, the incentives provided for the tenants of SEZs may drive up the rents and land prices in and around the SEZ area, potentially offsetting the financial benefits provided by the park.

The direct causal link between SEZs and a strong STI base is difficult to disentangle from the impact of forces of agglomeration. This explains why SEZs do not appear as an attractive direct policy response to the targets, as categorized in Table 5.

In Ukraine's case, the first step should be to identify the clear policy target, which can shed light on the appropriate policy tools to achieve the target. Given Ukraine's earlier experience with establishing many SEZs and operationalizing only a few, establishing further SEZs is not an effective and efficient policy option at this stage. 


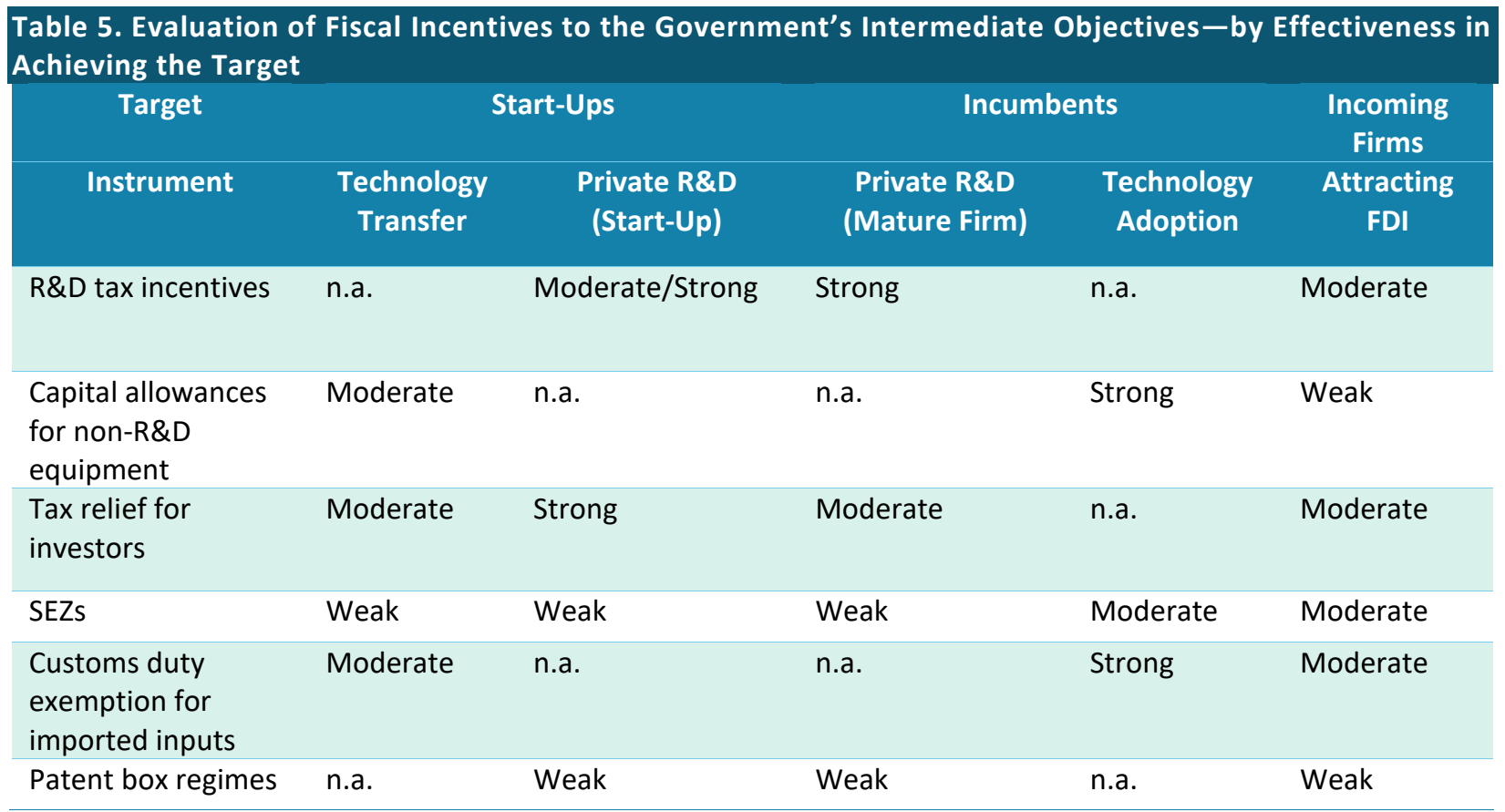

Each of the fiscal policy tools covered in this report has advantages and some caveats (Table 6). First and foremost, each policy option requires state capacity and political commitment within the Ministry of Finance to design, implement, monitor, and evaluate. Results of such monitoring and evaluation may lead to adjustments in policy design.

Regarding individual policy options, R\&D tax incentives are easier to implement than direct subsidies from the policy maker's perspective, but they can be costly in terms of foregone corporation tax revenue. Without institutional capacity in the Ministry of Finance for implementation, R\&D tax credits may result in a waste of valuable resources that should be used more effectively, especially given the current economic environment in Ukraine.

Capital allowances or exemptions for imported inputs are useful in promoting technology adoption and can be desirable depending on the policy objective, but these may impose an administrative burden to the relevant authorities that collect taxes or the applicable import duties. If the policy favors companies below a certain size, or investments up to a certain amount, firms may act strategically to position themselves around the eligibility thresholds, distorting firm size, which may have an impact on overall efficiency. Capital allowances are also found to be largely ineffective for loss-making companies-impact evaluations suggest that firms value these benefits if they are available immediately.

Finally, tax reliefs for investors, based on income generated from investments in new and/or innovative ventures, require a lot of liquid investors in the market. The downside is that wealthy individuals will seize the opportunity of tax avoidance through the scheme, and investments may be determined by tax planning needs of individuals.

In light of these considerations, Ukraine needs a comprehensive approach to its policies for stimulating innovation activities in the private sector. At this stage, the country can take action in the following areas with recommended steps for each. 


\section{(a) Analyzing the current environment and conducting stocktaking exercises}

- Conduct systematic analyses of impediments to private R\&D, technology upgrading of the national economy, and attraction of knowledge-intensive investment. The analyses should be carried out in consultation with the private sector and other actors of the national innovation system.

- Collect reliable and systematic data on R\&D activities at the firm level for ex ante cost-benefit analyses and later for monitoring and evaluation.

- Create a system for monitoring and evaluation of effectiveness of tax incentives and for monitoring of tax benefits for large investment projects. Incentives' effectiveness can be evaluated through the calculation of the dollar cost of the jobs they create, based on total tax spending. It should be noted that a policy with a less-than-a-dollar return on foregone tax revenue may still be desirable, if the government believes that the spillovers or other benefits of R\&D activities that are difficult to quantify overcome the costs. A full welfare analysis may also be considered.

\section{(b) Establishing macroeconomic stability and improving the business climate}

- For the time being, Ukraine should focus on achieving macroeconomic stability and improving its investment climate. Given the issues in past investment policies of fragmentation and state capture, it is recommended that Ukraine should wait before introducing tax incentive schemes and/or SEZs until it builds institutional capacity. Another approach could be to consider implementing some small, carefully evaluated, and perhaps temporary, pilots to help build capacity (for example, existing SEZs could be used to pilot instruments and build some experience).

- Build an all-encompassing policy framework in the future, after establishing macro stability and more predictability about the political environment. Ukraine's EU Association Agreement is a valuable anchor in that regard. Once the macroeconomic and investment climate conditions have improved, the government may consider a policy framework with a mix of direct subsidies and $R \& D$ tax incentives. Before engaging in such a policy framework, ex ante cost-benefit analyses are strongly recommended.

- Set clear, broad targets under which specific policy measures will be determined. These broad targets could be enabling knowledge-based start-ups or attracting FDI in high-tech sectors.

- Consider a set of complementary policies (rather than a single popular policy tool that seems to work in other countries), including tax and nontax measures that could be used to overcome the identified impediments. The government should design clearly defined, transparent, and objective eligibility criteria and (if necessary) special incentive packages for anchor investors (who can generate significant multiplier effects). Time limits on incentives should be set. Tax incentives should be established in the Tax Code or in special laws. All measures should be coordinated at the regional and municipal levels. 


\section{(c) Increasing implementation capacity}

- Create a system for compliance within the tax administration. This will help monitor beneficiaries' activities to prevent noncompliance once fiscal incentives are put in place (noncompliance in this context refers to both intentional misreporting and unknowingly claiming wrong amounts/activities for tax benefits).

- Develop competencies of tax offices, authorities, and companies to facilitate transparency, dialogue, proper use of incentives, and prevent illicit behavior. Building capacity to assist companies that are applying for any kind of tax incentives should be included in these competencies.

- Ensure simplicity and policy predictability, as it is crucial for young and innovative firms to compete on a level playing field as more mature incumbents. Firms should be able to understand and apply the policies easily. 


\begin{tabular}{|c|c|c|}
\hline Policy Measure & Pros & Cons \\
\hline R\&D tax incentives & $\begin{array}{l}\text { - Allows firms to take the decision about which } \\
\text { R\&D projects have better prospects } \\
\text { - Least costly administration }\end{array}$ & $\begin{array}{l}\text { - Firms relabel ordinary spending as R\&D } \\
\text { - Profitable firms benefit more, swaying the benefit toward large incumbents as } \\
\text { opposed to young innovative start-ups } \\
\text { - Might be costly from a foregone revenue point of view } \\
\text { - May need to establish specialist units to assess compliance, which adds an } \\
\text { administrative cost }\end{array}$ \\
\hline Capital allowances & $\begin{array}{l}\text { - Enables technology adoption } \\
\text { - Alleviates financing constraints } \\
\text { - Literature finds that smaller firms benefit } \\
\text { more }\end{array}$ & $\begin{array}{l}\text { - Mostly promotes profit-making businesses or firms that expect to switch to profit } \\
\text { quickly } \\
\text { - Start-ups with access to finance issues cannot acquire the subsidized capital } \\
\text { - Less effective for loss-making firms }\end{array}$ \\
\hline $\begin{array}{l}\text { Income and capital gains } \\
\text { tax relief for investors }\end{array}$ & $\begin{array}{l}\text { - Reduces the costs and risks of operating in } \\
\text { the business angel/VC industry }\end{array}$ & $\begin{array}{l}\text { - Wealthy individuals perceive this as a tax-dodging opportunity without an interest } \\
\text { in the company } \\
\text { - Might be costly from a foregone revenue point of view }\end{array}$ \\
\hline $\begin{array}{l}\text { SEZs/science and } \\
\text { technoparks }\end{array}$ & $\begin{array}{l}\text { - Shared facilities benefit many firms, driving } \\
\text { the costs of capital goods } \\
\text { - Colocation may encourage university- } \\
\text { industry links }\end{array}$ & $\begin{array}{l}\text { - Drives rents up, to the detriment of smaller firms } \\
\text { - Real effect is hard to measure, as economics of agglomeration may be the reason } \\
\text { for success } \\
\text { - Burdensome administration }\end{array}$ \\
\hline $\begin{array}{l}\text { VAT exemptions for } \\
\text { imported inputs }\end{array}$ & $\begin{array}{l}\text { - Customs duty and tariff exemptions may } \\
\text { facilitate technology adoption without } \\
\text { distorting the production process } \\
\text { - Reduced cost of technology adoption } \\
\text { - May facilitate FDI (for example Chile) }\end{array}$ & VAT exemptions may be distortionary for production \\
\hline Patent box regimes & - An extra incentive for patentable inventions & $\begin{array}{l}\text { - Almost certain to only support large, established firms } \\
\text { - Encourages a 'race-to-the-bottom' in tax competition across countries }\end{array}$ \\
\hline
\end{tabular}




\section{References}

Abramovsky, L., and H. Simpson. 2011. "Geographic Proximity and Firm-University Innovation Linkages: Evidence from Great Britain." Journal of Economic Geography 11 (6): 949-977.

Aghion, P., and P. Howitt. 1992. "A Model of Growth through Creative Destruction." Econometrica 60 (2): 323-351.

Agrawal, A., C. Rosell, and T. S. Simcoe. 2014. Do R\&D Tax Credits Affect R\&D Expenditures by Small Firms? Evidence from Canada. Cambridge, MA: National Bureau of Economic Research.

Alstadsaeter, A., S. Barrios, G. J. Nicodeme, A. Skonieczna, and A. Vezzani. 2015. "Patent Boxes Design, Patents Location and Local R\&D." CESifo Working Paper Series, CESifo Group, Munich.

Arrow, K. 1962. "Economic Welfare and the Allocation of Resources for Invention." In The Rate and Direction of Inventive Activity: Economic and Social Factors (pp. 609-626). Cambridge, MA, USA: National Bureau of Economic Research.

Asawachintachit, Duangjai (Deputy Secretary General Thailand Board of Investment). 2015. Seven-Year Investment Promotion Strategy (2015-2021).

Bloom, N., R. Griffith, and J. M. van Reenen. 2002. "Do R\&D tax credits work? Evidence from a panel of countries 1979-1997." Journal of Public Economics 85: 1-31.

Bloom, N., M. Schankerman, and J. M. van Reenen. 2013. "Identifying Technology Spillovers and Product Market Rivalry." Econometrica 81: 1347-1393.

Correa, P., and I. Guceri. 2013. Tax Incentives for Research and Development. Washington, DC: World Bank.

Crepon, B., E. Duguet, and J. Mairesse. 1998. "Research, Innovation and Productivity: An Econometric Analysis at the Firm Level." Economics of Innovation and New Technology 7 (2): 115-158.

Ebrill, L., J. P. Bodin, M. Keen, and V. Summers. 2001. The Modern VAT. Washington, DC: International Monetary Fund.

European Bank of Reconstruction and Development \& The World Bank (2013). Business Environment and Enterprise Performance Survey (BEEPS).

European Commission. 2014. "A Study on R\&D Tax Incentives, Final Report." CPB in consortium with CAPP, CASE, CEPII, ETLA, IFO, IFS, IHS. Taxation Working Paper 52, European Commission, The Hague.

Fazzari, S., G. R. Hubbard, and B. Petersen, B. 1988. "Financing Constraints and Corporate Investment." Brookings Papers on Economic Activity 19 (1): 141-206. 
Gonzales-Uribe, J., and D. Paravisini. 2016. How Sensitive Is Entrepreneurial Investment to the Cost of Outside Equity? Evidence from an UK Tax Relief. Unpublished (abstract available on author's website).

Griffith, R., H. Miller, and M. O'Connell. 2014. "Ownership of Intellectual Property and Corporate Taxation." Journal of Public Economics 112: 12-23.

Griliches, Z. 1979. "Issues in Assessing the Contribution of Research and Development to Productivity Growth." Bell Journal of Economics 10 (1): 92-116.

Guceri, I. 2016. R\&D Tax Incentives. London: European Tax Policy Forum.

Hall, B. H., and J. Lerner. 2010. "The Financing of R\&D and Innovation." In Handbook of the Economics of Innovation, edited by B. H. Hall, \& N. Rosenberg, Vol. 1, 609-639. Amsterdam: Elsevier B.V.

Hall, B. H., J. Mairesse, and P. Mohnen. 2010. "Measuring the Returns to R\&D." In Handbook of the Economics of Innovation, edited by B. H. Hall, \& N. Rosenberg, Vol. 2, 1033-1082. Amsterdam: Elsevier B.V.

Hall, B., and J. M. van Reenen. 2000. "How Effective Are Fiscal Incentives for R\&D? A Review of the Evidence." Research Policy 29, 449-469.

Hall, R. E., and D. W. Jorgenson. 1967. "Tax Policy and Investment Behavior." American Economic Review 57: 391-414.

IMF (International Monetary Fund). 2015. Options for Low Income Countries' Effective and Efficient Use of Tax Incentives for Investment. Washington: International Monetary Fund.

Jaffe, A. B. 1986. "Technological Opportunity and Spillovers of R\&D: Evidence from Firms' Patents, Profits, and Market Value." American Economic Review 76 (5): 984-1001.

James, S. 2013. Tax and Non-Tax Incentives and Investments: Evidence and Policy Implications. SSRN.

Jorgenson, D. W. 1963. "Capital Theory and Investment Behaviour." American Economic Review 53: 247-259.

Kaplan, Zeynep. 2011. "Technoparks in Turkey: A Source of Technological Development?" Paper prepared for European Commission Conference on Corporate R\&D.

Kravchuk, K. 2015. Any Change in the Role of Ukrainian Small Business? http://4liberty.eu/any-changein-the-role-of-ukrainian-small-business/

Liakhovets, Olena. 2014. "Tax Incentives Effectiveness for the Innovation Activity of Industrial Enterprises in Ukraine." Economics and Sociology 7 (1): 72-84.

Lokshin, B., and P. Mohnen. 2011. “How Effective Are Level-Based R\&D Tax Credits?" Evidence from the Netherlands 44 (12): 1527-1538. 
Maffini, G., J. Xing, and M. P. Devereux. 2016. The Impact of Investment Incentives: Evidence from uk Corporation Tax Returns. Oxford: Oxford University Centre for Business Taxation.

Mulkay, B., and J. Mairesse. 2013. "The R\&D Tax Credit in France: Assessment and Ex Ante Evaluation of the 2008 Reform." Oxford Economic Papers, 746-766.

Myers, S. C., and N. S. Majluf. 1984. "Corporate Financing and Investment Decisions When Firms Have Information That Investors Do Not Have." Journal of Financial Economics 13 (2): 187-221.

Norton Francis. 2016. State tax incentives for economic development. Urban Institute.

OECD. 2017a. R\&D Tax Incentive Country Profiles: 2016 France, Measuring R\&D Tax Incentives.

Directorate for Science, Technology and Innovation. Paris: OECD

- - . 2017b. Tax Incentives for Investment: A Global Perspective: Experiences in MENA and nonMENA Countries. Paris: OECD.

OECD (Organisation for Economic Co-operation and Development)-NESTI. 2013. Data Collection on Tax Incentive Support for R\&D Expenditures. Paris: OECD.

PriceWaterhouseCoopers. 2008. International Good Practice for Establishment of Sustainable IT Parks. Washington, DC: InfoDev, World Bank.

Rao, N. 2016. "Do Tax Credits Stimulate R\&D Spending? The Effect of the R\&D Tax Credit in Its First Decade." Journal of Public Economics 140: 1-12. New York: Elsevier.

World Bank. 2011. Special Economic Zones: Progress, Emerging Challenges, and Future Directions, edited by T. Farole and G. Akinci.

World Bank. 2015. Malaysia: Impact of tax incentives.

World Bank. 2017. Doing Business Report.

World Bank. 2017. Instruments to Support Business Innovation: A Guide for Policymakers and Practitioners.

World Bank. 2017. Ukraine Public Finance Review. June 27, 2017.

Tirole, J. 1988. The Theory of Industrial Organization. Cambridge, MA: MIT Press.

Zwick, E., and J. Mahon. 2017. "Tax Policy and Heterogeneous Investment Behavior." American Economic Review 107 (1): 217-248. 


\section{Appendix I. Country Examples of SEZs}

This appendix includes a brief description of tax incentives for SEZs in eight different countries and economic impact of such incentives (where relevant data are available).

\section{The Philippines}

Philippine Economic Zone Authority offers the following tax incentives: ${ }^{10}$

1. Income tax holiday (ITH)-100 percent exemption from corporate income tax:

- Four years ITH for non-pioneer projects

- $\quad$ Six years ITH for pioneer projects

ITH extension years may be granted if a project complies with the following criteria (one criterion is equivalent to one ITH extension year), if the total ITH entitlement period shall not exceed eight years:

- The average net foreign exchange earnings of the project for the first three years of operations is at least US\$500,000.00.

- The capital equipment to labor ratio of the project does not exceed US\$10,000.00 to US\$1 for the year immediately preceding the ITH extension year being applied for.

- The average cost of indigenous raw materials used in the manufacture of the registered product is at least fifty percent (50 percent) of the total cost of raw materials for the preceding years before the ITH extension year.

- Three years ITH for expansion projects (ITH applies to incremental sales)

Upon expiry of the ITH -5 percent special tax on gross income and exemption from all national and local taxes.

2. Tax and duty-free import of raw materials, capital equipment, machineries, and spare parts

3. Exemption from wharfage dues and export tax, impost, or fees

4. VAT zero rating of local purchases subject to compliance with BIR and PEZA requirements

5. Exemption from payment of any and all local government imposts, fees, licenses, or taxes

However, while under the ITH, no exemption from real estate tax, but machineries installed and operated in the economic zone for manufacturing, processing, or industrial purposes shall be exempt from real estate taxes for the first three years of operation of such machineries. Production equipment not attached to real estate is exempted from real property taxes.

10 http://www.sciencepark.com.ph/en/peza-tax-incentives/ 
6. Exemption from expanded withholding tax.

Non-fiscal incentives include simplified import-export procedures (Electronic Import Permit System and Automated Export Documentation System) and a special regime for employing foreigners. The incentives are also provided to the residents of the Science Park of the Philippines and six industrial parks under the Science Park.

\section{Taiwan}

Taiwan provides the tax incentives detailed in table 1.1 for science parks, export processing zones (EPZs), agricultural biotechnology parks, bonded factories, bonded warehouses, logistics centers, and free trade zones. ${ }^{11}$

${ }^{11}$ More information on Taiwan's tax system is available at http://investtaiwan.nat.gov.tw/eng/show.jsp?ID=36\&MID=2 


\begin{tabular}{|c|c|c|c|c|c|c|c|}
\hline $\begin{array}{c}\text { Items Eligible } \\
\text { for Indirect } \\
\text { Tax }\end{array}$ & EPZ & Science Park & $\begin{array}{c}\text { Agricultural } \\
\text { Biotechnology } \\
\text { Park }\end{array}$ & $\begin{array}{l}\text { Bonded } \\
\text { Factory }\end{array}$ & Bonded Warehouse & Logistics Center & Free Trade Zone \\
\hline $\begin{array}{l}\text { Import of raw } \\
\text { materials from } \\
\text { overseas }\end{array}$ & $\begin{array}{l}\text { Exempted } \\
\text { from customs } \\
\text { duty, } \\
\text { commodity } \\
\text { tax, business } \\
\text { tax, and trade } \\
\text { promotion } \\
\text { service fees }\end{array}$ & $\begin{array}{l}\text { Exempted } \\
\text { from customs } \\
\text { duty, } \\
\text { commodity } \\
\text { tax, business } \\
\text { tax, and trade } \\
\text { promotion } \\
\text { service fees }\end{array}$ & $\begin{array}{l}\text { Exempted from } \\
\text { customs duty, } \\
\text { commodity tax, } \\
\text { business tax, } \\
\text { and trade } \\
\text { promotion } \\
\text { service fees }\end{array}$ & $\begin{array}{l}\text { Exempted } \\
\text { from } \\
\text { customs } \\
\text { duty, } \\
\text { commodity } \\
\text { tax, business } \\
\text { tax, and } \\
\text { trade } \\
\text { promotion } \\
\text { service fees }\end{array}$ & $\begin{array}{l}\text { Exempted from } \\
\text { customs duty, } \\
\text { commodity tax, } \\
\text { business tax, tobacco } \\
\text { and wine tax, public } \\
\text { health and welfare } \\
\text { dues on tobacco } \\
\text { products, trade } \\
\text { promotion service } \\
\text { fees, and harbor } \\
\text { service dues }\end{array}$ & $\begin{array}{l}\text { Exempted from } \\
\text { customs duty, } \\
\text { commodity tax, } \\
\text { business tax, tobacco } \\
\text { and wine tax, public } \\
\text { health and welfare dues } \\
\text { on tobacco products, } \\
\text { trade promotion service } \\
\text { fees, and harbor service } \\
\text { dues }\end{array}$ & - \\
\hline $\begin{array}{l}\text { Import of } \\
\text { goods for } \\
\text { operation } \\
\text { purposes from } \\
\text { overseas }\end{array}$ & - & - & - & - & - & - & $\begin{array}{l}\text { Exempted from } \\
\text { customs duty, } \\
\text { commodity tax, } \\
\text { business tax, tobacco } \\
\text { and wine tax, public } \\
\text { health and welfare dues } \\
\text { on tobacco products, } \\
\text { trade promotion service } \\
\text { fees, and harbor service } \\
\text { dues }\end{array}$ \\
\hline $\begin{array}{l}\text { Import of fuel, } \\
\text { supplies, } \\
\text { semifinished } \\
\text { materials from } \\
\text { overseas }\end{array}$ & $\begin{array}{l}\text { Exempted } \\
\text { from customs } \\
\text { duty, } \\
\text { commodity } \\
\text { tax, business } \\
\text { tax, and trade } \\
\text { promotion } \\
\text { service fees }\end{array}$ & $\begin{array}{l}\text { Exempted } \\
\text { from customs } \\
\text { duty, } \\
\text { commodity } \\
\text { tax, business } \\
\text { tax, and trade } \\
\text { promotion } \\
\text { service fees }\end{array}$ & $\begin{array}{l}\text { Exempted from } \\
\text { customs duty, } \\
\text { commodity tax, } \\
\text { business tax, } \\
\text { and trade } \\
\text { promotion } \\
\text { service fees }\end{array}$ & - & $\begin{array}{l}\text { Exempted from } \\
\text { customs duty, } \\
\text { commodity tax, } \\
\text { business tax, trade } \\
\text { promotion service } \\
\text { fees, and harbor } \\
\text { service dues }\end{array}$ & $\begin{array}{l}\text { Exempted from } \\
\text { customs duty, } \\
\text { commodity tax, } \\
\text { business tax, trade } \\
\text { promotion service fees, } \\
\text { and harbor service dues }\end{array}$ & 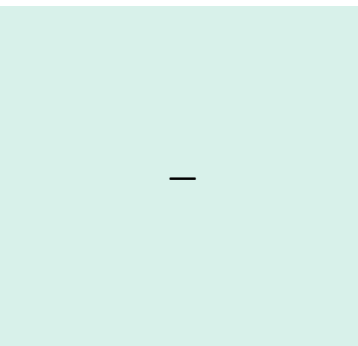 \\
\hline
\end{tabular}




\begin{tabular}{|c|c|c|c|c|c|c|}
\hline $\begin{array}{l}\text { Import of } \\
\text { machinery } \\
\text { from overseas }\end{array}$ & - & - & - & $\begin{array}{l}\text { Exempted } \\
\text { from } \\
\text { customs } \\
\text { duty, } \\
\text { commodity } \\
\text { tax, business } \\
\text { tax, and } \\
\text { trade } \\
\text { promotion } \\
\text { service fees }\end{array}$ & - & $\begin{array}{l}\text { Exempted from } \\
\text { customs duty, } \\
\text { commodity tax, } \\
\text { business tax, trade } \\
\text { promotion service fees, } \\
\text { and harbor service dues }\end{array}$ \\
\hline
\end{tabular}


All of the abovementioned infrastructures is offered 0 percent VAT on export of products/services and on purchase of raw materials, fuel, supplies, and semifinished materials from nonbonded area.

Taiwan's Hsinchu Science and Industrial Park, recognized as one of the successful examples at the global level, offers the following incentives: ${ }^{12}$

1. Tax incentives

- No import duty, commodity tax, or business tax will be imposed on machineries, instruments, raw materials, fuel, materials, and semifinished products imported by a park enterprise for its own use. The enterprise is also excused from the off-duty, warrant, filing, or tax mortgage process. However, in case of exporting the mentioned items to taxed regions, enterprises should pay import duty, commodity tax, and business tax according to regulations.

- All products or labor outputs exported by park enterprises are exempted from business taxation.

- Corporate income tax: 17 percent.

2. Protection of investors' rights

3. Investors can apply for the government's investment participation; the government investment can be as high as 49 percent of the total capital.

4. Upon certification by authentic organizations, in the form of technology capitalization evaluation documents, together with approvals of shareholders' broad, a park tenant company may apply to the Division of Business Services of the Science Park Bureau to issue new stocks or to register modifications of new stocks regarding innovative technology know-hows.

5. In case of capital raising demand, local or foreign investors may raise capital through assistances of the Taiwan Venture Capital Association.

6. Incentives for R\&D

- The Science Park Bureau provides tenants innovative technology industry-academia cooperation project grants, with a maximum grant of NTD 10 million. The grant, however, could not exceed 50 percent of project budget.

- R\&D expenses can be deducted from corporate income tax up to 15 percent but the total deducted expenses cannot exceed 30 percent of the total corporate income tax.

- R\&D equipment can be exempted from import duties.

7. Incentives regarding the Act Governing Biotech and New Medicine Industry Development

- Listed shareholders investing in biotech or new medicine corporations for more than three years can be exempted from corporate income tax within five years, up to a total of 20 percent of the price of stock shares gained. For entities of venture capitalists, corporate income tax can be exempted from the fourth year of stock shares gained, with the same period of five

12 Hsinchu science and industrial park website: http://www.sipa.gov.tw 
years.

- $\quad R \& D$ and talent cultivation expenditure

- 35 percent of R\&D expenditure can be deducted from corporate income tax within five years of a real corporate profit gain.

- Amount of R\&D expenditure exceeding the averaged amount of former two years, the exceeded portion of R\&D expenditure enjoys a deduction rate of 50 percent from corporate income tax.

\section{- Attraction of R\&D talent}

- Technology trade-off income enjoys suspended levy of income tax, where tax levying year can be suspended to a time when stock shares are transferred, given as presents, or distributed inherited assets, based on the real transacted price subtracting the gained cost, no limit for the suspended tax payment period.

- If government employees are the main providers for emerging corporate biotech and medicine technologies, the government employees can possess more than 10 percent of the corporate shares as the corporation starts and can act as the corporation initiators, presidents, or technology consultants, out of the confinement of the Act Governing Government Employee Services. R\&D staff of academia or research institutes can act as $R \& D$ consultants in the biotech medicine corporation.

\section{Malaysia}

Malaysia provides a special tax incentive-pioneer status. ${ }^{13}$ The standard pioneer status regime provides a tax exemption of 70 percent of statutory business income (income after deduction of capital allowances and allowable expenses) for five years. An enhanced version of this regime is provided to activities and sectors of special strategic importance for Malaysia, including high-tech firms and investments in selected industries. This regime increases the tax exemption to 100 percent of statutory business income, as well as in some cases increasing the period of eligibility for the incentive from five to ten years. Under the pioneer status, manufacturing SMEs are provided with an income tax exemption of 100 percent of the statutory income for five years. ${ }^{14}$ Small-scale companies are provided with the same income tax exemption or income tax allowance (ITA) of 60 percent on the qualifying capital expenditure incurred within five years (World Bank 2015).

Special tax incentives are offered in agriculture and agro-based industries for operators of parks that produce halal products: pioneer status with income tax exemption of 100 percent of SI for a 10 years or ITA of 100 percent on the QCE incurred within 10 years.

Malaysia also offers tax incentives for economic development in specific geographic areas-the following

\footnotetext{
${ }_{13}$ Pioneer status targets desirable or 'promoted' activities and sectors, providing a partial or total income tax exemption for a number of years to attract foreign domestic investment or to encourage domestic investment in these promoted areas.

${ }^{14}$ Applies to SMEs defined as Manufacturing Companies with shareholders' funds not exceeding RM 500,000 and at least 60 percent Malaysian-owned equity. Existing proprietorships or partnerships are eligible, provided a new private limited/limited company is formed to take over the existing production/activities. Companies have to comply with either of the following criteria: the value added created must be at least 15 percent; or the project must contribute towards socioeconomic development of the rural population.
} 
five economic growth corridors were established:

- $\quad$ East Coast Economic Region

- Northern Corridor Economic Region (NCER)

- Iskandar Malaysia - South Johor

- Sabah Development Corridor

- Sarawak Corridor of Renewable Energy (SCORE)

In these regions, various tax incentives are provided, such as income tax exemptions, ITAs, sales tax exemptions, import duty exemptions, and customized incentives (case-by-case basis). Incentives are different in each economic corridor and for different sectors. The most relevant to the scope of the present analysis are tax incentives provided in the East Coast Economic Region. In addition to general tax incentives for this region, incentives are given to petrochemical industry for:

(a) Companies developing infrastructure of an industrial park:

- Income tax exemption of 100 percent for 10 years commencing from the year company derives statutory income or ITA of 100 percent on qualifying capital expenditure for five years

- Stamp duty exemption on instruments of acquisition or leasing of property relating to industrial park

(b) Companies undertaking promoted activities in a park:

- Customized incentives based on the merit of each case or income tax exemption of 100 percent for eight years commencing from the year company derives statutory income or ITA of 100 percent on qualifying capital expenditure for five years

- Import duty and sales tax exemption on raw materials, components, machinery, equipment, spare parts, and consumables that are not produced locally and used directly in the activity

Special incentives are also provided in the area of manufacturing for companies developing infrastructure of industrial parks: income tax exemption of 100 percent for five years commencing from the year company derives statutory income or ITA of 100 percent on qualifying capital expenditure for five years. They also receive stamp duty exemption on instruments of acquisition or leasing of property relating to industrial parks. Companies undertaking promoted activities in the industrial park receive the following privileges:

- Customized incentives based on the merit of each case or income tax exemption of 100 percent for eight years commencing from the year company derives statutory income or ITA of 100 percent on qualifying capital expenditure for five years

- Import duty and sales tax exemption on raw materials, components, machinery, equipment, spare parts, and consumables that are not produced locally and used directly in the activity

Iskandar Malaysia - South Johor provides special incentives for high-tech projects in the area of electric and electronics, petrochemicals and oleochemicals, food, and agro-processing: pioneer status with 
income tax exemption of 100 percent of statutory income for five years or ITA with 60 percent on the qualifying capital expenditure incurred within five years, set off against 100 percent of statutory income.

In Sabah Development Corridor, tax incentives are given to the Palm Oil Industry Cluster for downstream activities (manufacturing of oleochemicals, biofuel, trans-fat free food products): full tax exemption on statutory income for 10 years or ITA of 100 percent on qualifying capital expenditure for 5 years (can be offset against 100 percent of statutory income, subject to qualifying activities/products under the Promotion of Investment Act 1986). Incentives are also provided to Sabah Oil and Gas Industrial Park to support downstream activities (manufacturing-medium and heavy industries, urea and ammonia production, solar glass, ship building and repairs), marine supply base and fabrication yard, iron ore palletizing, hot briquette iron, combined cycle power plant: full tax exemption on statutory income for 10 years or ITA of 100 percent on qualifying capital expenditure for five years (can be offset against 100 percent of statutory income, subject to qualifying activities/products under the Promotion of Investment Act 1986). For the ship building and repairs industry, incentives are offered under Income Tax Act 1967: full tax exemption on statutory income for five years or ITA of 100 percent on qualifying capital expenditure for five years (can be offset against 100 percent of statutory income).

Sandakan Education Hub (private universities and colleges, training centers, and skill training centers) and Marine Integrated Cluster (production of aquaculture products and seafood, fresh and dried export, and production of cosmetics material and pharmaceuticals) provide full tax exemption on statutory income for 10 years or ITA of 100 percent on qualifying capital expenditure for five years (can be offset against 100 percent of statutory income) as well as exemption on import duty and sales tax exemption on equipment and machines used, subject to current policy.

In Malaysia, tax incentives are granted by the Ministry of Finance but administered by a number of Investment Promotion Authorities (IPAs). The main IPA is the Malaysian Investment Development Authority (MIDA). Other IPAs include both those focusing on specific sectors (such as the Multimedia Development Corporation and the Halal Development Corporation) as well as geographic areas (such as Iskandar Malaysia or the East Coast Economic Region). Under the current system, firms must apply for incentives with the IPAs, which assess the application against a number of set criteria and approve incentives conditional on the firm achieving certain benchmarks (generally related to the amount of investment undertaken and employment). Incentives in manufacturing are product specific, so that tax deductions must relate to the production of the promoted product(s) only. Increasingly, and particularly in services sectors, 'customized' (nonstandard) incentives can be negotiated between firms and the IPAs. IPAs conduct a form of cost-benefit analysis (CBA) when considering whether to grant incentives and make recommendations to the Investment Committee chaired by the Tax Analysis Division at the Ministry of Finance. The Investment Committee generally approves the recommendation of the IPAs for standard incentives on a no-objection basis, but in some cases, including all 'customized' incentives the committee debates the merits of individual projects and may require modifications to the conditionality (World Bank 2015).

The World Bank survey conducted in Malaysia in 2015 concluded that tax incentives increased the amount that firms invested-31 percent of investors increased the amount invested as a result of incentives by an average of 37 percent. There is also some evidence from Malaysia that foreign firms benefiting from ITA create productivity spillovers to domestic firms that act as clients of foreign firms (World Bank 2015).

\section{Thailand}

In Thailand, special tax incentives are provided to companies in priority industries. The most supported areas are so-called groups 'A1' (knowledge-based activities, focusing on R\&D and design to enhance the 
country's competitiveness) and 'A2' (activities on infrastructure for the country's development, activities using advanced technology to create value added). Companies in these groups are provided with eightyear exemptions on corporate income tax and import duty on machinery/raw materials. The country also stimulates decentralization of the economy by providing incentives to projects located in 20 provinces with the lowest per capita income (these incentives are given in addition to that provided for specific areas). For example, projects in groups $\mathrm{A} 1$ and $\mathrm{A} 2$ receive 50 percent corporate income tax reduction for five years after the end of corporate income tax exemption period, while projects in other selected areas receive only three years of corporate income tax exemption. Projects located in industrial estates or promoted industrial zones (group A activities only) receive one additional year of corporate income tax exemption.

Thailand also selected five border provinces to be developed as SEZs. These zones offer the following tax incentives:

- Three additional years of corporate income tax exemption (in cases where projects are already granted an eight-year corporate income tax exemption, an additional five-year 50 percent corporate income tax reduction is granted instead)

- Exemption of import duty on machinery

- Exemption of import duty on raw materials used for export production (Asawachintachit 2015)

\section{Bangladesh}

EPZs provide the following tax incentives (World Bank 2011):

- 10-year tax holiday and additional five years at 50 percent

- Duty-free import and export of raw materials and finished goods

- Duty-free import of construction materials, equipment, office machinery, and spare parts

- Relief from double taxation

- Exemption from dividend tax

- Duty-free import of two to three vehicles for use in EPZs

- Expatriates exempted from income tax for three years

- Accelerated depreciation allowance on machinery or plant

- Remittance of royalty, technical, and consultancy fees allowed

Bangladesh's EPZ program has been quite successful in attracting investment: between 1994 and 1999, average annual investment flows into the EPZs were US\$52 million; this grew to US\$88 million in the subsequent five years (2000-2004) and nearly doubled to US\$172 million in 2005-2008. Exports grew rapidly, at an average annual rate of 23 percent from 1993 to reach nearly US\$2.5 billion by 2008 (World Bank 2011). 


\section{Honduras}

In Honduras, free zones provide generous tax incentives from an international perspective. Free zonebased companies are exempt from all federal and municipal taxes, as well as duties and charges associated with trade. There is no time limit attached to the tax incentives. These incentives are summarized in table 1.2 (World Bank 2011.

\section{Table 1.2. Honduras Tax Exemptions for Free Trade and EPZs}

\begin{tabular}{|c|c|c|}
\hline Incentives & Free trade zone & Export processing zone \\
\hline $\begin{array}{l}\text { Imported duties on raw materials, } \\
\text { components }\end{array}$ & $100 \%$ exemption & $100 \%$ exemption \\
\hline Export taxes & $100 \%$ exemption & $100 \%$ exemption \\
\hline Local sales and excise taxes & $100 \%$ exemption & $100 \%$ exemption \\
\hline Taxes on net assets & $100 \%$ exemption & $100 \%$ exemption \\
\hline Taxes on profits & $100 \%$ exemption & $100 \%$ exemption \\
\hline Municipal taxes and obligations/duties & $100 \%$ exemption & $100 \%$ exemption \\
\hline Taxes on profits repatriation & $100 \%$ exemption & $100 \%$ exemption \\
\hline Capital repatriation & $100 \%$ exemption & $100 \%$ exemption \\
\hline Currency conversion & Unrestricted & Unrestricted \\
\hline Customs & Cleared on site & Cleared on site \\
\hline $\begin{array}{l}\text { Sales to } \\
\text { local market }\end{array}$ & $\begin{array}{l}5 \% \text { of total production paying customs } \\
\text { duties }\end{array}$ & $\begin{array}{l}\text { Only paying customs duties authorized } \\
\text { by the Secretariat of Industry and } \\
\text { Trade }\end{array}$ \\
\hline Eligibility requirements & $\begin{array}{l}\text { Industrial and commercial companies } \\
\text { can be established }\end{array}$ & $\begin{array}{l}\text { Industrial and commercial companies } \\
\text { can be established }\end{array}$ \\
\hline
\end{tabular}

Source: Special Economic Zones, World Bank, 2011.

The Honduras Free Zones Program has proven to be effective-exports from such zones have grown rapidly since the early 1990s. Value added export earnings reached US\$3.3 billion in 2007, which is 10 times higher than those in 1993 (equivalent to 20 percent average growth each year over that period). It should be noted that Honduras has more than three decades of experience of hosting free zones, and it took approximately 15 years before the policy brought economic impact. In addition to U.S. demand, the key to takeoff in the early 1990s was all the crucial conditions with regard to infrastructure, free zone policy, trade policy, and committed domestic investors were in place. Tax incentives have played a role in attracting investment into the free zone program, both from FDI and local investors (World Bank 2011.

\section{China}

A remarkable example of an international zone is Suzhou industrial park created together by China and Singapore. The park was developed in the early 1990s and has emerged as a major success. It has attracted more than 4,900 foreign-invested enterprises, including 88 Fortune 500 multinational enterprises investing in 148 projects, with an accumulative contractual foreign investment of US\$45 billion, and over 
18,000 domestic companies. ${ }^{15}$ The park has built a reputation as one of the most business-friendly, residential-friendly, and environment-friendly industrial parks in China. ${ }^{16}$ The park provides additional incentives for high-tech companies. Such companies can apply for a Hi-New Technology Enterprises certificate. Once approved, they can enjoy a special corporate income tax rate at 15 percent, instead of 25 percent for normal enterprises. Furthermore, high-tech (especially biopharmaceutical, medical devices, nanotech, cloud computing) and R\&D centers can enjoy many other preferential policies and tailored incentives such as business tax exemption, R\&D expense deduction before taxation, tax rebate, start-up fund, rental subsidy, salary subsidy, training subsidy, loan guarantee, and so on. The important factor for high-tech companies is that the park has a well-developed environment for innovation, including special infrastructure (International Science Park, Creative Industry Park, Nanopolis, Biobay, SinoSingapore Science Hub, and so on), shared platforms with related equipment in many technology areas, offices of VC and private equity companies, IP protection system (including a special fund), serviceoriented government system, and a full range of services for businesses. ${ }^{17}$

\section{Turkey}

In Turkey, technoparks began as an initiative to provide tax incentives to companies that perform R\&D. The law establishing these technopark incentives was adopted in 2001, and many innovative firms located or relocated in these special zones, which were mostly close to or within university campuses. The special status of technoparks gradually led to a rapid increase in office rents. There were some additional restrictions related to the technopark residents. Most employees needed to enter at the start of the business day and leave at the end. In other words, overtime or any other outside-hours work was not counted in work that was subject to the tax incentives. This was reported to be a challenge for innovative start-up companies.

In 2008, Turkey adopted a new law making tax incentives more widely available to companies that are outside technoparks. The 2008 law, however, restricted many tax benefits to large employers of R\&D personnel, and this left many smaller players to remain in technoparks and pay large rents for the office space. Recently, the Turkish government amended the law that provides R\&D tax incentives to cover smaller companies as well, rendering technoparks as centers that promote collaboration between companies, universities, and research institutes, as well as providing infrastructure and some advisory services (technology transfer offices, IP advice, and other consultancy services).

The technopark law that was adopted in 2001 (and most provisions of the later R\&D law expanding the tax incentives to firms that are not technopark residents) offers the following incentives (Kaplan 2011):

- Income and corporate tax exemptions for the operating company

- Income and corporate tax exemptions for the incomes generated from software development and R\&D activities of the companies operating in these zones

- Income tax exemptions for the salaries of the researchers, software development staff, and R\&D personnel working in these zones

- VAT exemptions for the software development activities

15 http://www.nanoinnovationcenter.com/?page id=277

${ }^{16}$ Special Economic Zones. Progress, Emerging Challenges, and Future Directions, Edited by T. Farole and G. Akinci, World Bank, 2011.

17 http://www.nanoinnovationcenter.com/?page id=277 
- Right of recruitment of individuals from government research organizations or universities in the zone with the approval of their organizations (the income obtained in the zone by academics or research personnel are exempted from the university revolving fund deductions)

- Legal permission for academics to establish firms or become a partner of existing firms in the zones to commercialize their academic works (with the approval of their university) (Kaplan 2011)

Turkish technoparks' exports grew from US\$144 million in 2006 to US\$540 million in 2011. Although this volume is small compared to similar parks in other countries, it has been steadily increasing over time (Kaplan 2011).

The World Bank's Innovation Ecosystem Overview for Turkey (2016) notes that the incentives provided for technoparks in Turkey and for other companies that are included in the 'R\&D center' definition are similar, owing to the amendments to the law governing the definition of an 'R\&D center'. The report also notes that some companies that fulfill the new 'R\&D center' definition leave the technoparks. This is due to the high rents for technopark office spaces. Based on this observation, the report recommends that Turkey focuses on value added services offered by technoparks, instead of making them a center to limit $R \& D$ tax incentives. 
结 Sida

(4) WORLDBANGGROUP 